Article

\title{
New Malolactic Bacteria Strains Isolated from Wine Microbiota: Characterization and Technological Properties
}

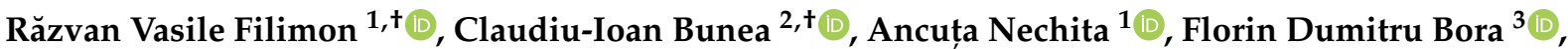 \\ Simona Isabela Dunca ${ }^{4}{ }^{\mathbb{D}}$, Andrei Mocan ${ }^{5,6}$ and Roxana Mihaela Filimon ${ }^{1, *}$
}

check for

updates

Citation: Filimon, R.V.; Bunea, C.-I.; Nechita, A.; Bora, F.D.; Dunca, S.I.; Mocan, A.; Filimon, R.M. New Malolactic Bacteria Strains Isolated from Wine Microbiota:

Characterization and Technological Properties. Fermentation 2022, 8, 31. https://doi.org/10.3390/ fermentation 8010031

Academic Editor: Sergi Maicas

Received: 17 December 2021

Accepted: 11 January 2022

Published: 13 January 2022

Publisher's Note: MDPI stays neutral with regard to jurisdictional claims in published maps and institutional affiliations.

Copyright: (C) 2022 by the authors. Licensee MDPI, Basel, Switzerland. This article is an open access article distributed under the terms and conditions of the Creative Commons Attribution (CC BY) license (https:// creativecommons.org/licenses/by/ $4.0 /)$.
1 Research Development Station for Viticulture and Winemaking Iasi, 48 Mihail Sadoveanu Alley, 700490 Iasi, Romania; razvan_f80@yahoo.com (R.V.F.); ancuta.vasile@yahoo.com (A.N.)

2 Faculty of Horticulture, University of Agricultural Sciences and Veterinary Medicine Cluj-Napoca, Calea Mănăştur 3-5, 400372 Cluj-Napoca, Romania; claudiu.bunea@usamvcluj.ro

3 Research and Development Station for Viticulture and Winemaking Bujoru, 65 G-ral. Eremia Grigorescu Street, Târgu Bujor, 805200 Galați, Romania; boraflorindumitru@gmail.com

4 Faculty of Biology, Al. I. Cuza University of Iasi, 11 Carol I Boulevard, 700506 Iasi, Romania; sdunca@uaic.ro

5 Laboratory of Chromatography, Institute of Advanced Horticulture Research of Transylvania, University of Agricultural Sciences and Veterinary Medicine, 400372 Cluj-Napoca, Romania; andrei.mocan@usamvcluj.ro

6 Faculty of Pharmacy, Iuliu Hațieganu University of Medicine and Pharmacy, Victor Babeș 8, 400012 Cluj-Napoca, Romania

* Correspondence: roxanacotovanu@yahoo.com

$\dagger$ These authors share the same contribution and should be both seen as first authors.

\begin{abstract}
Malolactic fermentation (MLF) or biological decrease of wine acidity is defined as the enzymatic bioconversion of malic acid in lactic acid, a process performed by lactic acid bacteria (LAB). The procedures for the isolation of new indigenous LAB strains from the red wines produced in Copou Iasi wine center (NE of Romania) undergoing spontaneous malolactic fermentation, resulted in the obtaining of 67 catalase-negative and Gram-positive LAB strains. After testing in the malolactic fermentative process, application of specific screening procedures and identification (API $50 \mathrm{CH}$ ), two bacterial strains belonging to the species Oenococcus oeni (strain 13-7) and Lactobacillus plantarum (strain R1-1) with high yield of malolactic bioconversion, non-producing biogenic amines, and with active extracellular enzymes related to wine aroma, were retained and characterized. Tested in synthetic medium (MRS-TJ) for 10 days, the new isolated LAB strains metabolized over $98 \%$ of the malic acid at ethanol concentrations between 10 and $14 \%(v / v)$, low $\mathrm{pH}(>3.0)$, total $\mathrm{SO}_{2}$ doses up to $70 \mathrm{mg} / \mathrm{L}$ and temperatures between 15 and $35^{\circ} \mathrm{C}$, showing high potential for future use in the winemaking process as bacterial starter cultures, in order to obtain high quality wines with increased typicity.
\end{abstract}

Keywords: biogenic amines; extracellular enzymes; indigenous microbiota; malolactic bioconversion; lactic acid bacteria

\section{Introduction}

It is generally accepted that wine is the result of two biological processes of fermentationalcoholic and malolactic bioconversions-determined by the microorganisms that develop on grapes during ripening. If in the alcoholic fermentation grape sugars are metabolized by yeasts and transformed into ethanol and carbon dioxide, in the case of malolactic fermentation (MLF), under the action of lactic acid bacteria, L-malic acid of wine is decarboxylated to L-lactic acid, with the production of varying concentrations of secondary fermentation metabolites. Broadly, for each gram of malic acid fermented, $0.67 \mathrm{~g}$ of lactic acid and $0.33 \mathrm{~g}$ of carbon dioxide are produced [1].

In winemaking, MLF is one of the most difficult processes to control and can affect the aroma and taste balance of the final product [2]. Conducted under optimum conditions, 
MLF showed important effects on wine quality: it reduces acidity and slightly increases the $\mathrm{pH}$, increases the biological stability of the wine by avoiding subsequent uncontrolled fermentations, and changes the aroma and taste of the wine, increasing its complexity $[3,4]$.

$\mathrm{LAB}$ involved in the winemaking process belongs to the Lactobacillus, Leuconostoc, Oenococcus, and Pediococcus genera, with Oenococcus oeni and Lactobacillus plantarum as the most used species for conducting controlled MLF [4-6]. The selection of new LAB for starter cultures requires the assessment of many properties related to the new strain including resistance to biotic and abiotic stresses, technological performances, and safety aspects [7]. After isolation from indigenous microbiota, selection of LAB strains for starter cultures involves various screening procedures, including testing of the malolactic bioconversion yield, the ability of bacteria to produce undesirable or even toxic fermentation by-products (acetic acid, ethyl carbamate, biogenic amines, acetoin or diacetyl, acrolein, mannitol). Screening of LAB strains for wine inoculation also requires testing in synthetic media in order to observe their survival in wine-like conditions and monitoring the consumption of L-malic acid

The use in winemaking of the selected LAB starter cultures have the advantage of a controlled fermentation process, but is also beneficial for the complexity of the aromatic profile. Beside primary aroma of grapes, various flavours are produced during fermentation processes by extracellular enzymes secreted by yeasts and bacteria. In the case of spontaneous MLF, the range of extracellular enzymes is much larger and varied due to the participation of many LAB species. This explains why the wines obtained by spontaneous malolactic fermentation have a much more complex aromatic profile, compared to the wines obtained by monoculture innoculation. Thus, the presence of extracellular enzymes influences the wine aromas, increasing the typicity of wines.

It is known that malolactic bacteria strains showed high phenotypic variability in terms of tolerance to harsh environmental conditions and malolactic activity. The survival and growth of the bacteria are dependent on certain conditions, such as temperature, $\mathrm{pH}$, sulfur dioxide, ethanol, and malic acid levels and the ability to synthesize specific enzymes. Selection of LAB strains for wine inoculation should essentially be based on a high malolactic activity under harsh conditions (low $\mathrm{pH}$, high ethanol, and sulphur dioxide concentrations) [8,9]. Generally, microorganisms have an optimal $\mathrm{pH}$ range of development. Additionally, $\mathrm{pH}$ plays an important role in determining which LAB species will survive and develop [10]. Moreover, different LAB species exhibited versatile enzymatic activities from acidic to alkaline $\mathrm{pH}$ conditions [11]. Temperature influences the rate of cell growth, the duration of the lag phase, and the final density of the bacterial population $[2,10]$. LAB are mesophilic species with an optimal development at temperatures between 27 and $30{ }^{\circ} \mathrm{C}[12,13]$.

McKay et al. [14] showed that sulfur dioxide $\left(\mathrm{SO}_{2}\right)$ has a much more inhibitory effect on bacteria than on yeasts. For LAB inhibition, a level of free $\mathrm{SO}_{2}$ above $10 \mathrm{mg} / \mathrm{L}$ and a total $\mathrm{SO}_{2}$ concentration above $30 \mathrm{mg} / \mathrm{L}$ was suggested [4,15]. Moreover, ethanol strongly interferes with the growth and metabolic activity of LAB [2]. The development of LAB and implicitly the MLF dynamics decreased with the increase of the alcoholic concentration of the medium to a maximum of $14.50 \%(v / v)$ [16]. Thus, for wines with alcohol concentration above $14-15 \%(v / v)$, an alcohol tolerant LAB strain should be isolated and used.

Given the importance of the biological factors involved in the MLF process, continuous isolation, selection, and characterization of LAB strains from various vineyards is required, being attested that the most appreciated wines, characterized by a higher typicity, are obtained when the microorganisms used for conducting wine biotechnological processes are isolated and selected from the indigenous microbiota of the respective vineyard. The production of wines using selected wild microorganism strains is a useful tool in improving the quality of wines. Moreover, wild strains of lactic acid bacteria may help to produce modern and new wine styles in a climate change viticultural environment [17].

Considering that in many wine regions of the world the use of LAB starter cultures to initiate MLF has not yet become a routine practice and that the typicity of the wines can 
be much amplified by the use of carefully selected LAB strains, the aim of this work was the characterisation and assessment of technological properties of new malolactic bacteria strains isolated from red wine microbiota, in order to determine their potential to be used as starter cultures to induce the malolactic fermentation of wine.

\section{Materials and Methods}

\subsection{Climatic Conditions of the Vineyard}

The Iaşi vineyard is located in the northeast of Romania, $47^{\circ} 10^{\prime}$ northern latitude and $27^{\circ} 35^{\prime}$ eastern longitude, presenting favorable conditions for the grapevine growing. The climate is temperate continental with excessive nuances, characterized by large contrasts between seasons, with harsh and dry winters, hot and often droughty summers. The plot was planted at an altitude of $184 \mathrm{~m}$, on a slight slope (3\%) with southern exposition; orientation of rows N-S. The climate analysis of the last 20 years indicates an average annual temperature of $10.5^{\circ} \mathrm{C}$, with a maximum value of $11.6^{\circ} \mathrm{C}$ in 2019 and a minimum of $9.5^{\circ} \mathrm{C}$ in 2001. Grapevines were 15 years old, grafted on the hybrid rootstock Kober 5 BB (Vitis berlandieri Planch. $\times$ Vitis riparia Michx.).

\subsection{Isolation and Purification of Indigenous $L A B$ Strains}

Tested LAB strains were isolated after the alcoholic fermentation of grape must (Fermactive CB S. cerevisiae, Sodinal, France), from red wines ( $V$. vinifera L. cultivars: Merlot, Cabernet Sauvignon, Arcaş, Fetească neagră and Pinot noir) undergoing spontaneous malolactic fermentation. Wines were obtained from the 2018 harvest through the classic winemaking technology (grape crushing and destemming). The main physico-chemical parameters of wines were determined according to the Compendium of international methods of wine and must analysis of OIV [18]. Wine samples were collected aseptically, $1 \mathrm{~mL}$ of wine being used to obtain decimal dilutions $\left(10^{-1}\right.$ to $\left.10^{-4}\right)$ in sterile distilled water. The dilutions obtained were inoculated on agarised De Man, Rogosa, Sharpe (MRS) medium [19], supplemented with $5 \mathrm{~g} / \mathrm{L}$ malic acid, $1 \% \mathrm{CaCO}_{3}(\mathrm{pH} 4.5)$ and $100 \mathrm{mg} / \mathrm{L}$ of cycloheximide (to suppress yeast growth) and incubated at $30{ }^{\circ} \mathrm{C}$ for 5 days in anaerobiosis (GENbag anaerobic ${ }^{\circledR}$; BioMérieux, France).

\subsection{Preliminary Selection of $L A B$ Strains}

For the preliminary selection of the bacterial isolates, a catalase test was performed by rapid technique (a drop of 3\% hydrogen peroxide was added to a loopful LAB culture) and Gram staining. After microscopic examination of strain purity, isolates were preserved in MRS broth supplemented with $30 \%$ glycerol at $-20^{\circ} \mathrm{C}$ [20].

To define the type of fermentative metabolism of glucose, the production of $\mathrm{CO}_{2}$ was highlighted by growing de LAB isolates in Clark-Lubs broth medium ( $0.5 \%$ peptone, $0.5 \%$ dipotassium phosphate, $0.5 \%$ glucose; $\mathrm{pH} 7.5$ ), in test tubes with Durham tubes added prior to sterilization. After inoculation $\left(10^{8} \mathrm{CFU} / \mathrm{mL}\right)$, a layer of mineral oil (liquid paraffin) was added to each test tube. Gas accumulation in tubes after $24 \mathrm{~h}$ of incubation at $30^{\circ} \mathrm{C}$ was taken as the evidence for $\mathrm{CO}_{2}$ production from glucose.

In order to determine the fermentative capacity of LAB strains, the isolates were inoculated in synthetic wine with $12 \%(v / v)$ ethanol ( $\mathrm{pH} 3.5)$, at $28{ }^{\circ} \mathrm{C}$, without shaking, at a cell density of $10^{8} \mathrm{CFU} / \mathrm{mL}$, after prior acclimation in modified MRS broth with $10 \%$ $(v / v)$ ethanol ( $\mathrm{pH} 4.6)$, according to the protocol presented by Bravo-Ferrada et al. [21]. Monitoring of the MLF process was performed by thin layer chromatography (TLC), using cellulose plates $20 \times 20 \mathrm{~cm}$ (Merck, Germany) and a mixture of solvents as mobile phase: n-butanol: distilled water: acetic acid: bromophenol blue, in a ratio of 100:20:20:0.1 (v/v/v/w).

\subsection{Screening of Extracellular Enzyme Production}

LAB strains were screened for extracellular enzymes associated with wine aroma: $\beta$-glucosidase, esterase, lipase, protease, and pectinase. For all the tests, LAB cells were grown for $48 \mathrm{~h}$ on MRS broth at $30^{\circ} \mathrm{C}$, centrifuged (10 min., $4000 \mathrm{RPM}$ ), inoculated by 
loop on Petri dishes with agarised modified MRS medium and specific substrates, and then incubated at $30{ }^{\circ} \mathrm{C}$ for $4-5$ days. $\beta$-glucosidase activity was determined on modified MRS (0.5\% peptone, $1.0 \%$ beef extract, $2 \%$ agar) supplemented with $0.25 \%$ arbutin (pH 5.6 ). After autoclaving $\left(15 \mathrm{~min} ., 121^{\circ} \mathrm{C}\right), 2 \mathrm{~mL}$ of $1 \%$ ferric ammonium citrate solution were added to $100 \mathrm{~mL}$ medium [22]. LAB that produced $\beta$-glucosidase showed a brown halo around the colonies. Esterase activity was tested on agarised modified MRS ( $0.5 \%$ peptone, $0.5 \%$ beef extract, $0.5 \%$ yeast extract, $2 \%$ agar) supplemented with $0.01 \% \mathrm{CaCl}_{2}$ and $1.5 \%$ Tween 20 as substrate ( $\mathrm{pH}$ 6.8). LAB with esterase activity formed an opaque halo around the colonies. The assay of protease activity was performed on agarised modified MRS ( $0.5 \%$ yeast extract, $1.0 \%$ glucose, $0.5 \% \mathrm{NaCl}, 2 \%$ agar), $\mathrm{pH}$ 7.0. A solution of pasteurized skimmed milk $(<0.1 \%$ fat) diluted 1:1 with sterile distilled water was prepared separately. After sterilization of MRS medium, solutions were mixed and homogenized, distributed in Petri dishes and inoculated. Proteolytic LAB that hydrolyse milk casein showed a clear area around the colonies. The pectinase activity was tested on modified MRS medium (1.0\% glucose, $1.5 \%$ agar) with $0.5 \%$ apple pectin ( $\mathrm{pH} 7.0$ ). Afterwards, the incubation plates were flooded with a $1 \%$ hexadecyltrimethylammonium bromide solution (Sigma-Aldrich, Germany). A clear halo around the colonies indicates the pectinase activity. Lipase activity was tested on modified MRS agar $(0.5 \%$ peptone, $0.5 \%$ beef extract, $0.5 \%$ yeast extract, $2 \%$ agar) with $10 \mathrm{~mL} / \mathrm{L}$ of $0.001 \%$ rhodamine $B$ solution and $10 \mathrm{~mL} / \mathrm{L}$ olive oil as substrate. After incubation ( $3-5$ days, $30^{\circ} \mathrm{C}$ ), plates were revealed by UV irradiation at $\lambda 365 \mathrm{~nm}$ [23]. A commercial O. oeni strain, Viniflora Oenos ${ }^{\circledR}$ (Chr. Hansen, Denmark) was used as control for extracellular enzyme production.

\subsection{LAB Strains Identification}

Identification of LAB species was performed using the API $50 \mathrm{CH}$ kit (BioMérieux, France), which is a standardized system used to differentiate LAB isolates. The API technique consists in the inoculation of a pure bacterial suspension (McFarland standard no. 2), previously grown on MRS medium, in each of the 49 microtubes on the API $50 \mathrm{CH}$ strip, containing different carbohydrates (hexose, pentoses and others), as well as in the control microtube. All microtubes were covered with sterile mineral oil to achieve anaerobiosis. During incubation $\left(48 \mathrm{~h}, 37^{\circ} \mathrm{C}\right)$, carbohydrates are fermented to acids, causing the $\mathrm{pH}$ to drop, detected by the color change of the indicator, yellow indicating a positive character [5]. LAB identification was achieved after result patterns were analyzed and compared with the identification table provided.

\subsection{Characterisation of Indigenous LAB Strains}

The ability of LAB to use citrate as the sole source of carbon was tested on Simmon's citrate agar medium, with bromthymol blue as the $\mathrm{pH}$ indicator and sodium citrate as the source of carbon [24]. LAB that grows on this medium produced a color change from green (neutral) to blue (alkaline).

In order to highlight the production of acetoin (Voges-Proskauer reaction), LAB strains were grown on Clark-Lubs medium, at a cell density of $10^{8} \mathrm{CFU} / \mathrm{mL}$. After three days of incubation at $28{ }^{\circ} \mathrm{C}$, in $1 \mathrm{~mL}$ of the centrifuged medium was added $0.6 \mathrm{~mL}$ of $5 \% \alpha$-naphthol (in $96 \%$ ethanol) and $0.2 \mathrm{~mL}$ of $40 \% \mathrm{KOH}$, followed by vigorous stirring. After $15 \mathrm{~min}$ at room temperature $\left(20^{\circ} \mathrm{C}\right)$, the appearance of a pink-red color indicated the presence of acetoine.

The amino acid-decarboxylase test was performed in order to assess the production of biogenic amines through decarboxylation of amino acids by the LAB strains. Bacterial cells were plated on MDA medium (Modified Decarboxylating Agar) [25], with $4 \mathrm{~g} / \mathrm{L}$ of each tested amino acid (histidine, arginine, lysine, ornithine, and tyrosine), incubated in anaerobiosis at $28^{\circ} \mathrm{C}, 48 \mathrm{~h}$, after prior acclimation on MRS broth with $1 \mathrm{~g} / \mathrm{L}$ malic acid and $2 \mathrm{~g} / \mathrm{L}$ of each amino acid, at a cell density of $10^{9} \mathrm{CFU} / \mathrm{mL}$. The appearance of a purple area around the bacterial colonies indicated the ability of the tested strain to decarboxylate the amino acids. 
To evaluate the tolerance of $\mathrm{LAB}$ isolates to ethanol, $\mathrm{pH}, \mathrm{SO}_{2}$, malic acid and different temperatures and their malolactic performance in various growth conditions, $100 \mathrm{~mL}$ of MRS-TJ broth (MRS with 15\% tomato juice), with different $\mathrm{pH}$ values (3.0, 3.5, 4.0, 4.5), concentrations of malic acid $(2.0,3.0,5.0 \mathrm{~g} / \mathrm{L})$, total $\mathrm{SO}_{2}(0,10,30,50,70 \mathrm{mg} / \mathrm{L})$ and ethanol $(0,10,12,14 \% \mathrm{v} / \mathrm{v})$, were inoculated with $10^{6} \mathrm{CFU} / \mathrm{mL}$ of each tested bacteria and incubated for 10 days at $28^{\circ} \mathrm{C}, \mathrm{pH} 4.0$ (except for experimental variants with different $\mathrm{pH}$ values), in stationary conditions. In addition, the LAB strains were incubated at different temperature values $\left(15,22,28,35^{\circ} \mathrm{C}\right.$ ) in Bio concept incubators (Froilabo, France). Bacterial growth was monitored by spectrophotometric analysis of the cell density at $\lambda 600 \mathrm{~nm}$, according to the protocol presented by Bravo-Ferrada et al. [26]. The residual L-malic acid was determined using an enzymatic kit (code 12803; BioSystems, Spain), involving the activity of L-malate dehydrogenase and glutamate-oxaloacetate transaminase (GOT) at $37^{\circ} \mathrm{C}$ and reading the optical density at $\lambda 340 \mathrm{~nm}$ with a Pharmaspec ${ }^{\circledR}$ series $1700 \mathrm{UV}$-vis spectrophotometer (Shimadzu, Japan).

\subsection{Statistical Procedure}

Determinations were carried out in triplicate from independent cultures of each bacterial strain. Analysis of variance ANOVA test (XLSTAT 2021.5.1 for Microsoft ${ }^{\circledR}$ Excel) was initiated to investigate significant differences between data. $p$ values lower than 0.05 $(p<0.05)$ were considered to be significant. The method used to discriminate among the means was Tukey's test at 95\% confidence level. Regression analysis was performed to look for relationships between data. Principal Component Analysis (correlation type) with agglomerative hierarchical clustering (Ward's method) and histograms were performed to investigate data group formation (XLSTAT 2021.5.1 for Microsoft ${ }^{\circledR}$ Excel).

\section{Results and Discussion}

\subsection{Isolation of Indigenous $L A B$ Strains}

Initiated spontaneously after the alcoholic fermentation of grape must, MLF of red wines lasted between 25 and 28 days, at $20 \pm 2{ }^{\circ} \mathrm{C}$. At sampling, the wines achieved alcoholic concentrations between 11.50 and $13.50 \%(v / v), \mathrm{pH} 3.36-3.62(\mathrm{pH}$ meter InoLab Level 1, with SenTix 81 electrode; WTW, Germany), a total acidity of 5.25 to $6.12 \mathrm{~g} / \mathrm{L}$ tartaric acid, a volatile acidity of $0.34-0.39 \mathrm{~g} / \mathrm{L}$ as acetic acid, total sulphur dioxide $<15 \mathrm{mg} / \mathrm{L}$, and residual sugars below $1.00 \mathrm{~g} / \mathrm{L}$ (dry wines). Colonies that were grown on the surface of the agarised MRS medium after the incubation of the wine dilutions were counted, and the number of lactic acid bacteria was calculated in relation to the dilution performed. The number of $\mathrm{LAB}$ in wines varied from $16 \times 10^{3}$ (Pinot noir) to $58 \times 10^{3}$ (Arcaş) CFU $/ \mathrm{mL}$ (data not shown), concluding that the diversity and density of LAB are influenced by both the grape cultivar and microclimate conditions. Similar findings were previously reported by Muñoz et al. [27] and Dicks and Endo [28], which showed that the density of LAB in the initial phases of winemaking (the must phase and onset of alcoholic fermentation) ranges from approximately $10^{3}$ to $10^{4} \mathrm{CFU} / \mathrm{mL}$ and the numbers and proportions of species vary according to the ripeness and condition of the grapes at the time of harvesting. Moreover, De Orduna mentioned that climate conditions are exerting a profound influence on wine microbiology [29], while Bokulich et al. introduced the term "microbial terroir" as a determining factor in regional variation among wine grapes [30].

Individualized colonies that showed a clear halo on the carbonated agarised MRS medium (Figure 1a) were passed in MRS broth with $5 \mathrm{~g} / \mathrm{L}$ malic acid ( $\mathrm{pH} 4.5)$ and incubated in anaerobiosis at $30^{\circ} \mathrm{C}$ for $5-7$ days. For purification, bacterial cells were then cultivated repeatedly on agarised and broth MRS medium, in anaerobiosis, 5 days at $30^{\circ} \mathrm{C}$ (Figure 1b). After five successive subcultures on MRS medium, the colonies obtained were pure (Figure 1c). 


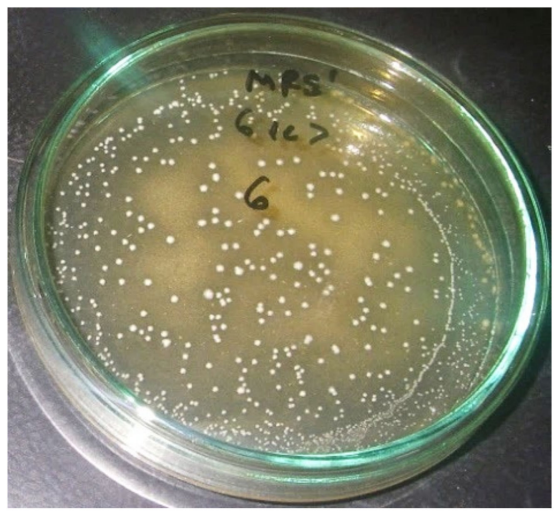

(a)

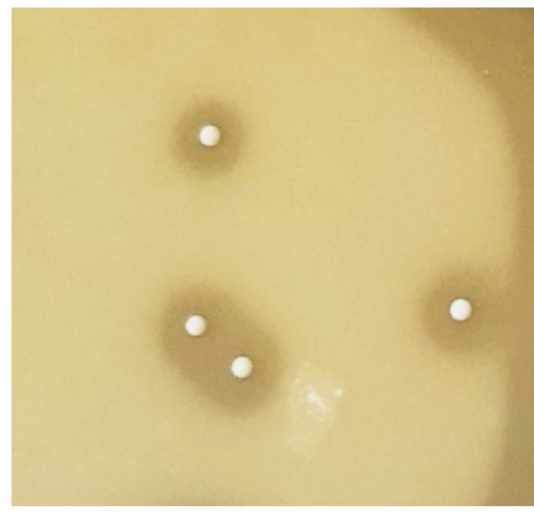

(b)

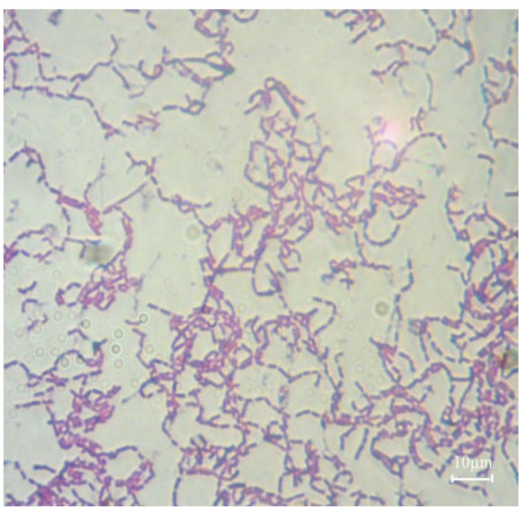

(c)

Figure 1. Macro- $(\mathbf{a}, \mathbf{b})$ and microscopic (c) aspect of the lactic acid bacteria colonies and Gramstained cells.

\subsection{Preliminary Selection of $L A B$ Strains}

$\mathrm{LAB}$ are Gram-positive, non-sporulated, immobile, and catalase-negative anaerobic microorganisms, tolerant to high concentrations of acids, bacteria that assimilate carbohydrates both in the homofermentative and heterofermentative pathways [12,31]. By macroscopic examination of morphological characteristics, LAB colonies showed circular shape, white color, and a small and milky aspect (Figure 1b). After microscopic examination of isolates purity, 67 bacterial strains showing LAB specific morphology (shape, sporulation, mobility) were selected and preserved in MRS broth supplemented with $30 \%$ glycerol at $-20^{\circ} \mathrm{C}$, a procedure that ensures the stability of the bacterial strains during storage.

After prior adaptation on MRS broth with $10 \%$ ethanol $(v / v)$, isolated LAB strains were inoculated in synthetic wine with $12 \%$ ethanol $(v / v)$, for 20 days at $28{ }^{\circ} \mathrm{C}$. Monitoring and completion of fermentation process in synthetic wine was performed by thin layer chromatography (TLC) (Figure 2). The retention factors (Rf) of the lactic and malic acids, calculated at a migration front of $7.5 \mathrm{~cm}$, were: $\mathrm{Rf}_{\text {malic acid }}=0.48$, respectively, $\mathrm{Rf}_{\text {lactic acid }}=0.75$.

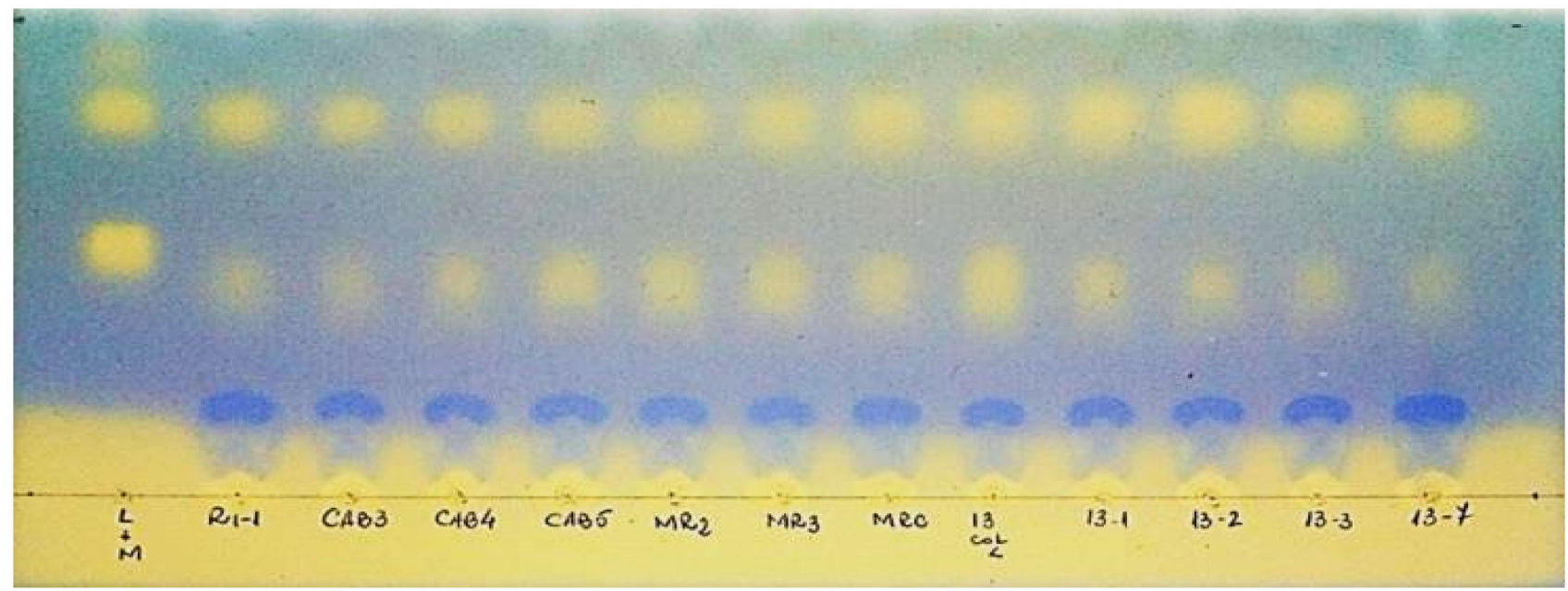

Figure 2. Thin layer chromatography of malic and lactic acids from synthetic wine (12\% v/v ethanol) inoculated with lactic acid bacteria (20 days, $28^{\circ} \mathrm{C}$ ). $\mathrm{L}+$ M-lactic acid (up) and malic acid (down) standards; R1-1... 13-7-bacterial strains.

The ability of indigenous LAB strains to metabolize malic acid was significantly different, forming several phenotypic groups: group I-three strains that have metabolized up to $25 \%$ of malic acid; group II-19 strains that have metabolized between 25 and $50 \%$ of 
the malic acid; group III-38 strains that have metabolized between 50 and $75 \%$ of the malic acid; group IV—-seven strains that have metabolized over $75 \%$ of the malic acid (Figure 3 ).

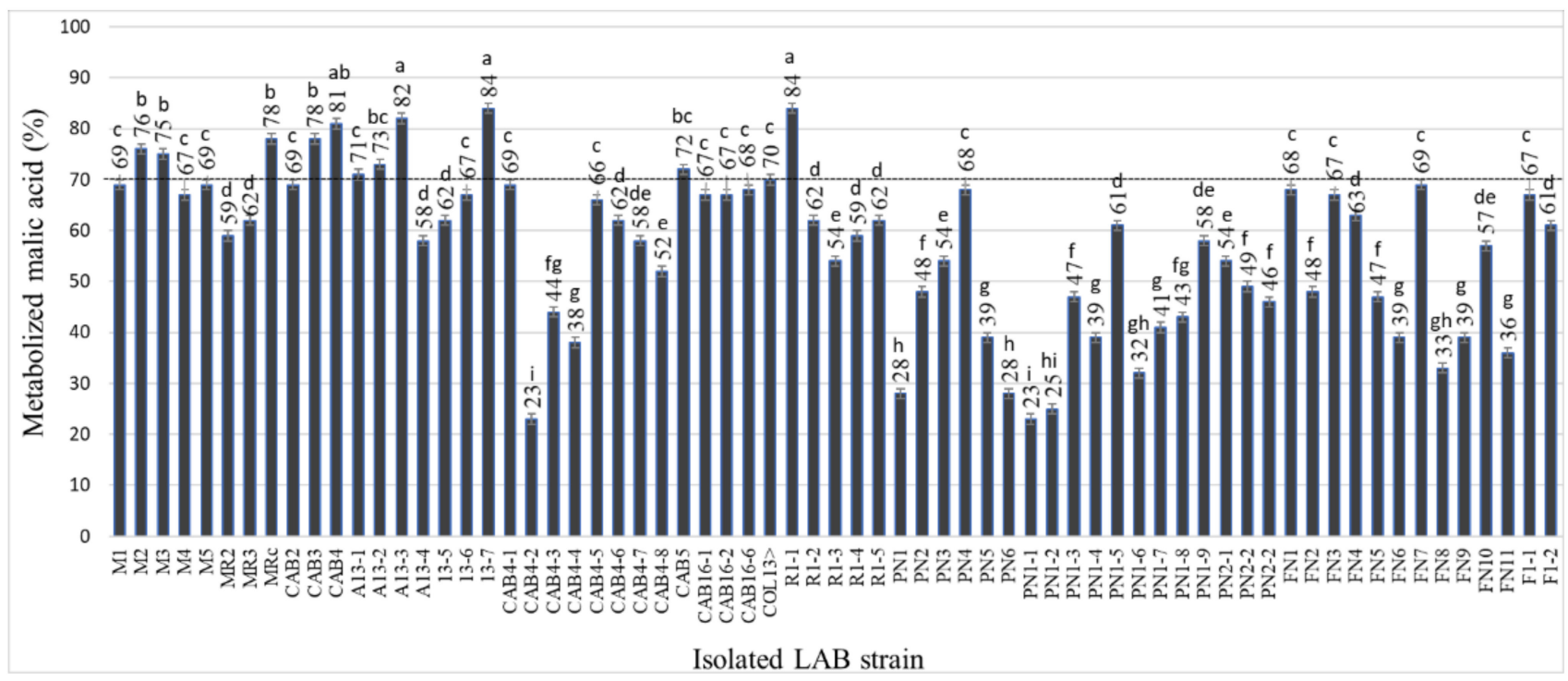

Figure 3. Malic acid bioconversion yield of lactic acid bacteria isolates in synthetic wine (12\% $v / v$ ethanol; $3 \mathrm{~g} / \mathrm{L}$ malic acid) after 20 days. Different letters indicate statistically significant differences between variables. Values with the same letter are not statistically significant $(p>0.05)$.

Cluster analysis admits the existence of polythetic groups (similar groups of individuals) and allows the verification of the belonging of an individual to a certain group, as well as the division of individuals into branches according to the principle of dissimilarity or similarity. Agglomerative hierarchical clustering (AHC) and dendrogram drawing based on the biodegradation capacity of malic acid, indicated the formation of two main clusters, obtained by the gradual aggregation of small groups of strains (Figure 4a). The formation of the two clusters indicates the direction of preliminary LAB screening in the study, respectively the selection of some strains belonging to the two main LAB genera (macro- and microscopic examination), Lactobacillus sp. and Oenococcus sp., capable of proper malolactic bioconversion. Moreover, according to the obtained histograms, data analysis revealed that most of the indigenous LAB isolated from the wine microbiota ( $>40 \%$ ) metabolized 60 to $75 \%$ of the available malic acid (relative frequency $=0.254$ ) (Figure $4 \mathrm{~b}$ ).

LAB strains that failed to convert at least $70 \%$ of the initial malic acid concentration in 20 days of fermentation were not considered technologically valuable. Thus, only 12 strains showing high potential for malolactic bioconversion were retained for the following stages of testing and characterization.

Examination of glucose metabolism revealed that of the 12 selected bacterial strains, 9 showed homofermentative metabolism and 3 heterofermentative metabolism (with $\mathrm{CO}_{2}$ release). According to Bauer and Dicks [10], Oenococcus oeni is a heterofermentative LAB species that produces lactic acid by glucose consumption and a variable number of secondary metabolites. In the case of the genus Lactobacillus, lactic acid bacteria species can be both heterofermentative and homofermentative [32]. If gas production is observed, the strain is heterofermentative, but this can also be confirmed by highlighting the presence of ethanol and acetic acid, a phenomenon valid for both genera Oenococcus and Lactobacillus. 


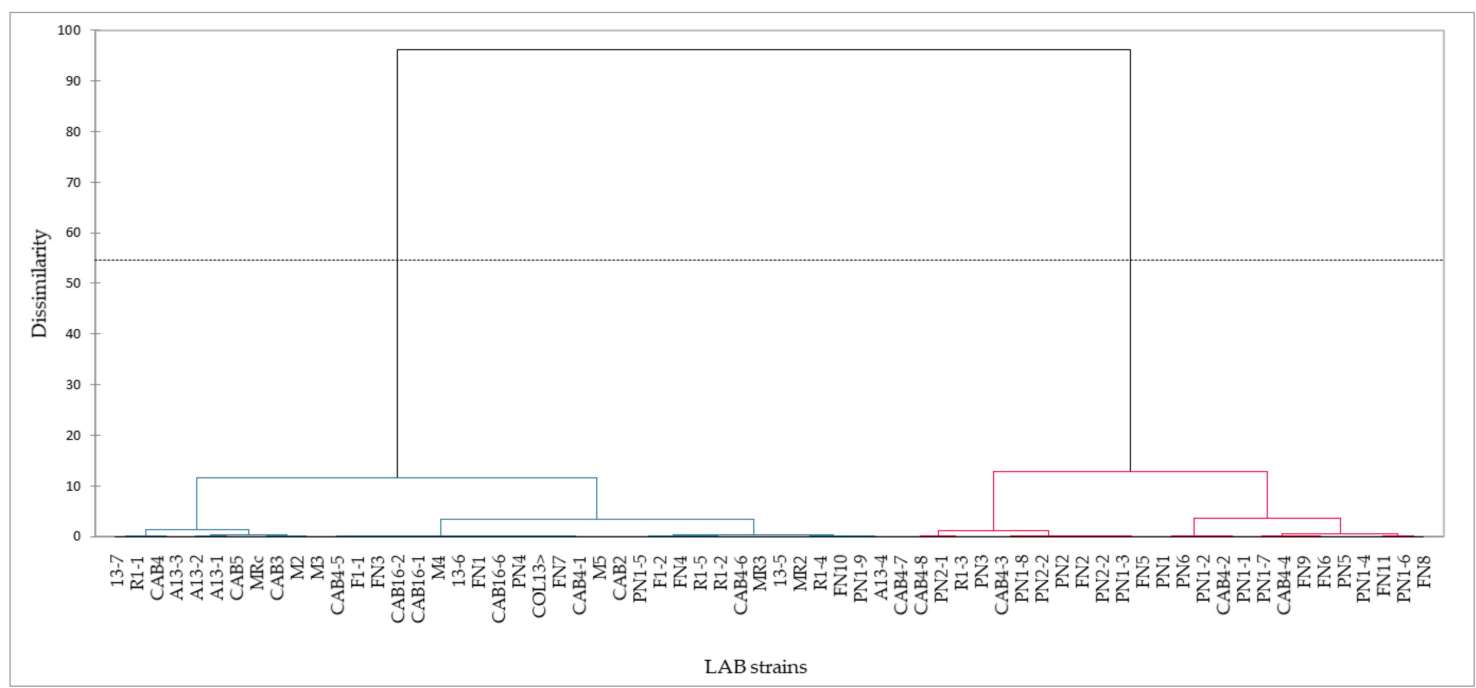

(a)

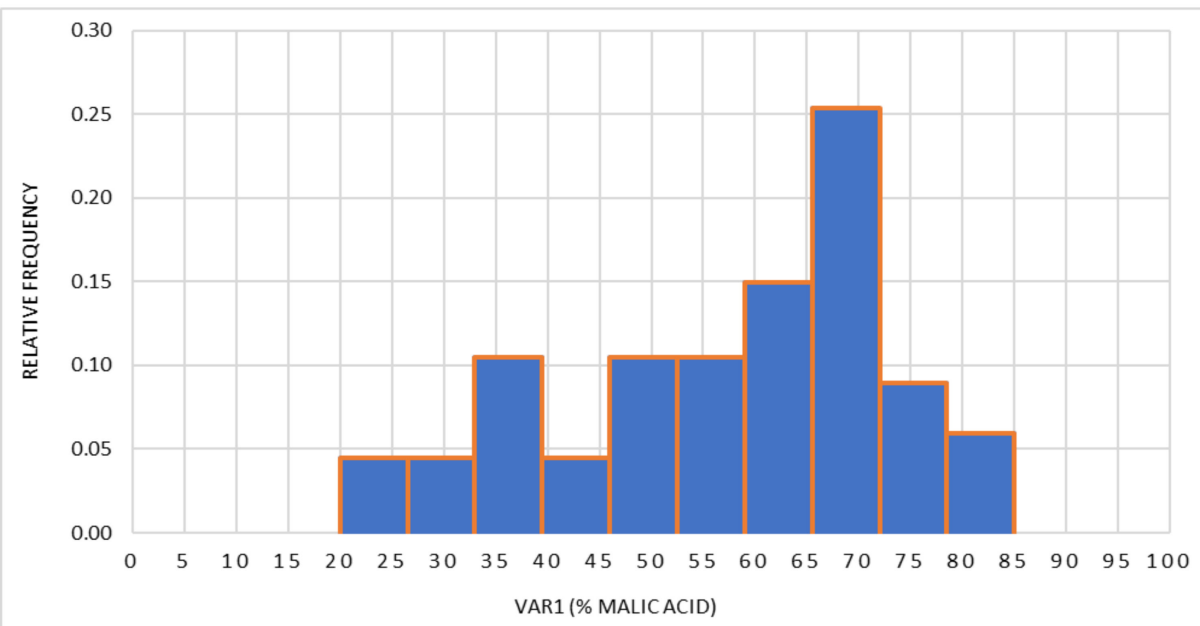

\begin{tabular}{ccccccc}
\hline Variable & Observations & $\begin{array}{c}\text { Obs. without } \\
\text { Missing Data }\end{array}$ & Minimum & Maximum & Mean & Std. Deviation \\
\hline Var1 & 67 & 67 & 23.000 & 84.000 & 57.224 & 15.847 \\
\hline
\end{tabular}

(b)

Figure 4. Dendrogram of isolated bacterial strains based on their ability to metabolize malic acid (a) and histogram of LAB group distribution (relative frequency) according to their malic acid bioconversion capacity (b).

\subsection{LAB Strains Identification}

Initially, the identification of LAB isolates was performed at the genus level. Thus, among 12 strains isolated, purified, and preliminary tested, 10 strains were taxonomically classified in the genus Lactobacillus (rod-shaped, bacilli; 9 homofermentative and 1 facultative heterofermentative-weak gas producer) and only 2 strains in the genus Oenococcus (ovoid to short rods, cocobacillus, in pairs and chains; heterofermentative).

Identification of LAB strains at the species level was performed according to the taxonomic keys established in Bergey's Manual of Systematic Bacteriology [12], using API 50 $\mathrm{CH}$ galleries (BioMerieux, France). API $50 \mathrm{CH}$ tests were used for phenotypic characterization of bacterial species isolated from grape must, wine, and dairy products, previous obtained results being highly correlated with genetic tests [26,33-35]. Each bacterial species ferments certain carbohydrates, making it possible to discriminate between them based on their fermentative preferences. After incubation and comparison of the results with the standard biochemical keys, the isolation of 10 bacterial strains belonging to the Lactobacillus 
plantarum species and 2 strains of Oenococcus oeni was confirmed. The differences were represented by the ability of the L. plantarum strain to ferment mannitol, melibiosis, sucrose, gentiobiosis, D-arabitol, and gluconate, while the O. oeni strain was able to ferment D-xylose and D-lixose.

\subsection{Screening of Extracellular Enzyme Production}

LAB may produce a wide range of enzymes such as: proteases, peptidases, polysaccharide degrading enzymes, ureases, lipases, amylases, esterases, and phenoloxidases [4]. Different strains of malolactic bacteria may increase or decrease the intensity of wine aroma and flavor attributes $[4,36]$. Depending on the number of extracellular enzymes, four groups of LAB strains were distinguished: group I-four strains with four extracellular enzymes (only L. plantarum strains); group II-two strains with three extracellular enzymes (only L. plantarum strains); group III-five strains with two extracellular enzymes, and group IV-one strain with one extracellular enzyme (O. oeni). All tested LAB strains showed extracellular protease with variable activity (Table 1).

Table 1. Extracellular enzymatic activity of the tested lactic acid bacteria strains.

\begin{tabular}{ccccccc}
\hline & & \multicolumn{5}{c}{ Enzymes and Substrates } \\
\cline { 3 - 6 } Lab Strain & Species & $\beta$-Glucosidase & Esterase & Lipase & Protease & Pectinase \\
\cline { 3 - 7 } & & Arbutin & Tween & Olive & Defatted & Apple \\
& & & $\mathbf{2 0}$ & Oil & Milk & Pectin \\
\cline { 3 - 6 } R1-1 & L. plantarum & + & +++ & + & +++ & - \\
M2 & L. plantarum & + & - & - & +++ & - \\
M3 & L. plantarum & + & - & - & ++ & - \\
MRc & O. oeni & - & - & - & ++ & + \\
CAB3 & L. plantarum & ++ & - & - & +++ & - \\
CAB4 & L. plantarum & + & - & - & +++ & - \\
CAB5 & L. plantarum & - & + & + & +++ & + \\
13 col. & L. plantarum & + & ++ & + & ++ & - \\
13-1 & L. plantarum & + & +++ & + & +++ & - \\
13-2 & L. plantarum & - & - & + & +++ & + \\
13-3 & L. plantarum & - & - & + & +++ & + \\
$13-7$ & O. oeni & - & - & - & ++ & - \\
Control & O. oeni & - & - & - & ++ & - \\
\hline Note: - no activity; + low activity; ++ medium activity; +++ high activity. & & &
\end{tabular}

Isolated O. oeni strains showed average activity of protease, similar to the commercial O. oeni control strain. All tested L. plantarum strains showed high protease activity (Figure 5a), only four strains showed variable esterase activity (Figure $5 b$ ), six strains presented lipase activity, while seven strains expressed $\beta$-glucosidase activity (Figure $5 c$ ). Davis et al. [37] found no wine LAB strains positive for extracellular protease; lipases were produced only by several strains of $O$. oeni and one strain of Lactobacillus sp., but the majority of LAB strains produced esterases.

$\beta$-glycosidase are enzymes involved in the hydrolysis of flavor precursors, releasing monoterpenes from the glycosylated form. Volatile compounds released from glycoside complexes play an important role in obtaining varietal aromas. Moreover, "lipolytic enzymes" such as lipases and esterases showed the ability to hydrolyze hydrophobic long- and short chain carboxylic acid esters [7]. Genetic studies performed by Lerm [38] by PCR detection of the associated genes demonstrated the presence of genes encoding $\beta$-glucosidase, esterase, and protease activity in L. plantarum strains, and esterase and protease in O. oeni strains. The L. plantarum strains were found to possess more diverse enzymatic profiles related to wine aroma than $O$. oeni, the biggest difference being for the presence of $\beta$-glucosidase. 


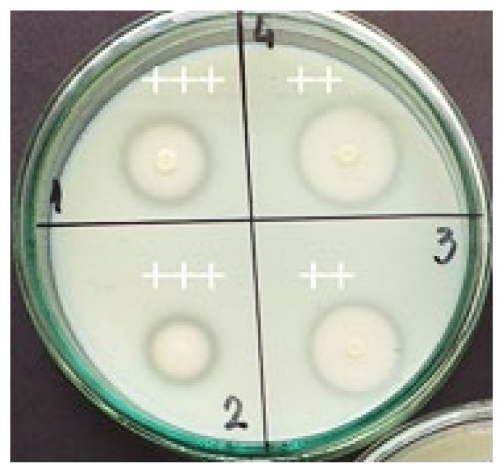

(a)

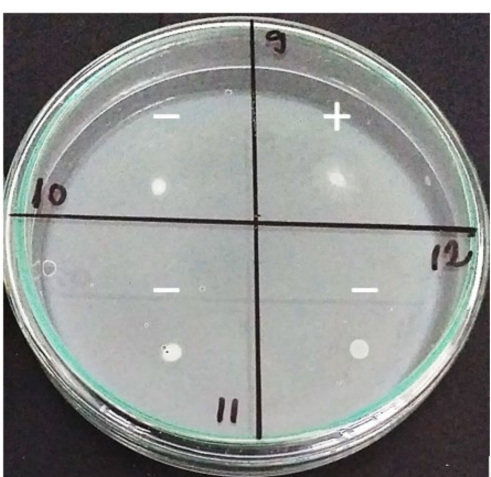

(b)

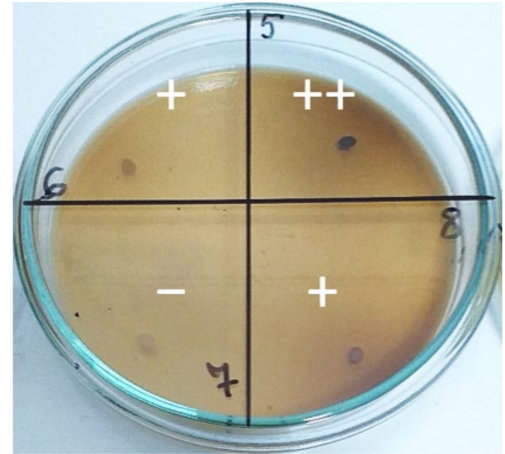

(c)

Figure 5. Extracellular enzymes production of indigenous lactic acid bacteria strains $\left(3-5\right.$ days, $\left.30^{\circ} \mathrm{C}\right)$. (a) Protease activity (a clear halo around the colonies indicates positive reaction); (b) Esterase activity (an opaque halo around the colonies indicates positive reaction); (c) $\beta$-glucosidase activity (a brown halo around the colonies indicates positive reaction);,,,-++++++ indicates no activity, low, average and high enzymatic activity, respectively.

\subsection{Characterisation of Indigenous LAB Strains}

Citrate-positive LAB are able to degrade citrate during MLF. These bacteria possess enzymes such as citrate-permeate and citrate-lyase, responsible for the degradation of citrate, while citrate-negative LAB lack these enzymes [4]. Citrate metabolism results in the production of various compounds (D-lactate, acetate, diacetyl, acetoin, 2,3-butanediol), which can influence the quality of wine [39]. Inoculated on Simmon's citrate agar medium, citrate-positive LAB strains weakly alkalized the culture medium, proving a reduced ability to metabolize citric acid (Figure 6a).

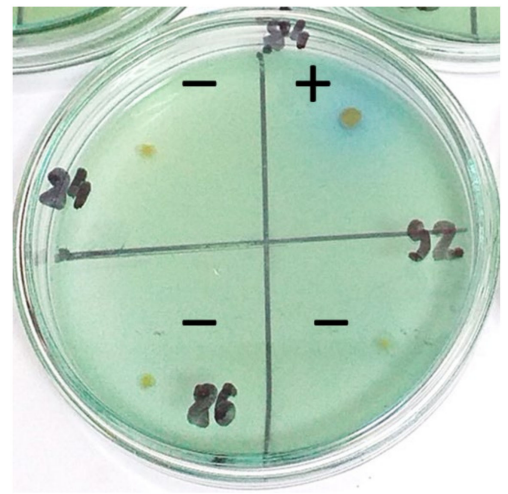

(a)

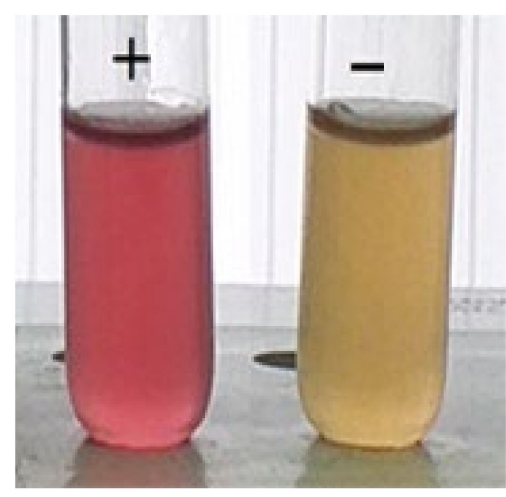

(b)

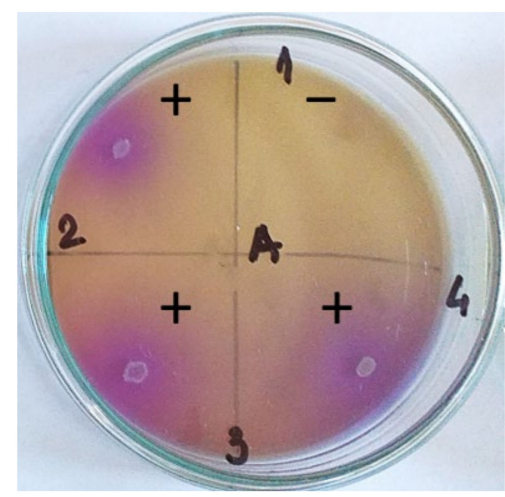

(c)

Figure 6. Physiological characterization of the tested lactic acid bacteria strains. (a) Use of citrate (the blue halo around the colonies indicates a positive reaction); (b) Acetoin production (VogesProskauer reaction; pink-red color indicates a positive reaction); (c) Amino acid-decarboxylase test (e.g., arginine; the purple halo around the colonies indicates a positive reaction); - and +, indicatespositive or negative reaction, respectively.

Of the $12 \mathrm{LAB}$ strains tested, only $4 \mathrm{~L}$. plantarum strains showed the ability to use citrate as the sole source of carbon and energy (Table 2). 
Table 2. $\alpha$-amino acid decarboxylation capacity, citrate consumption, and acetoin production of the tested lactic acid bacteria strains.

\begin{tabular}{|c|c|c|c|c|c|c|c|c|c|}
\hline \multirow{2}{*}{ StrainCode } & \multirow{2}{*}{ Species } & \multicolumn{5}{|c|}{ Amino Acids } & \multirow{2}{*}{$\begin{array}{c}\text { Citrate } \\
\text { Metabolism }\end{array}$} & \multicolumn{2}{|c|}{ Acetoin } \\
\hline & & Histidine & Arginine & Lysine & Ornithine & Tyrosine & & Glu & Cit \\
\hline R1-1 & L. plantarum & - & - & - & - & - & - & - & - \\
\hline M2 & L. plantarum & - & + & - & - & - & + & + & + \\
\hline M3 & L. plantarum & - & + & - & - & - & + & + & + \\
\hline $\mathrm{MRc}$ & O. oеni & - & + & - & - & - & - & + & - \\
\hline CAB3 & L. plantarum & - & + & - & - & - & - & - & - \\
\hline CAB4 & L. plantarum & + & - & - & - & - & + & + & + \\
\hline CAB5 & L. plantarum & - & + & - & - & - & - & + & - \\
\hline $13 \mathrm{col}$. & L. plantarum & + & + & - & - & - & + & - & + \\
\hline $13-1$ & L. plantarum & - & - & - & - & - & - & - & - \\
\hline $13-2$ & L. plantarum & - & + & - & - & - & - & + & - \\
\hline $13-3$ & L. plantarum & - & + & - & - & - & - & - & - \\
\hline 13-7 & O. oеni & - & - & - & - & - & - & - & - \\
\hline Control & O. оепi & - & - & - & - & - & - & - & - \\
\hline
\end{tabular}

Note: - negative reaction; + positive reaction; Glu-production of acetoin from glucose; Cit-production of acetoin from citrate; Control-commercial O. oeni strain (Viniflora Oenos ${ }^{\circledR}$, Chr. Hansen, Denmark).

The production of acetoin (acetylmethylcarbinol) from both glucose and citrate was tested by centrifugation of bacterial cell suspension of Simmon's broth and Clark-Lubs broth media and adding to the supernatant $\alpha$-naphthol as the catalyst and $\mathrm{KOH}$ as the oxidizing agent, which hastens the oxidation of acetoin to diacetyl (Voges-Proskauer test). The appearance of the pink-red color after vigorous aeration indicated the presence of acetoin (Figure $6 \mathrm{~b}$ ). The content of diacetyl found in wine is dependent on the LAB species used as a starter culture for MLF [2,40]. At low concentrations $(0.5-4 \mathrm{mg} / \mathrm{L})$ diacetyl is associated with the buttery character of wine, while at high concentrations $(>5-7 \mathrm{mg} / \mathrm{L})$ it confers undesirable aromas [41,42]. Among the tested LAB isolates, five L. plantarum strains and one O. oeni strain were able to produce acetoin from glucose metabolism, while only four L. plantarum strains were capable to produce acetoin from citrate (Table 2). LAB strains that consumed citrate as the sole source of carbon, also produced acetoine from citrate metabolization.

Biosynthesis of biogenic amines is achieved by decarboxylation of $\alpha$-amino acids by amino acid decarboxylase enzyme. These amines are compounds with low molecular weight, but with important biological activity. Relatively small amounts of biogenic amines as aliphatic polyamides (putrescine, cadaverine, spermine and spermidine are found in wine [43]. Heterofermentative LAB may degrade arginine during MLF via the arginine deiminase pathway, leading to the formation of ammonia, ornithine, citrulline, ATP, and $\mathrm{CO}_{2}$ [44]. Most biogenic amines are toxic to the body due to the physiological effects they produce in the presence of alcohol and acetaldehyde (headaches, hypotension, digestive disorders) and can imprint an unpleasant odor to wine [45]. In addition, the catabolism of arginine by $\mathrm{LAB}$ in wine can produce citrulline-like precursors for the formation of ethyl carbamate (urethane), a compound known for its carcinogenic activity [46]. Considering these food safety issues, spontaneous malolactic fermentation must be less and less present in wine technology, and research in this field needs to focus on the isolation and selection of new superior LAB strains to be used as starter cultures.

Tested LAB isolates did not show the ability to decarboxylate the amino acids tyrosine, ornithine, and lysine. Only two L. plantarum strains were able to decarboxylate histidine, but most of the LAB isolates (seven L. plantarum and one O. oeni) showed the capacity to decarboxylate arginine, with the formation of the corresponding amines (Figure 6c; Table 2).

In the experimental screening procedures, indigenous $\mathrm{LAB}$ isolates that were capable of producing biogenic amines and acetoin by using glucose or citrate were eliminated from the study. Thus, after performing the screening procedures, two bacterial strains belonging to the species Lactobacillus plantarum (strain R1-1) and Oenococcus oeni (strain 
13-7), respectively, were retained and further characterized. The selected bacterial strains showed a rate of malic acid conversion of over $80 \%$ in synthetic wine, and were not able to consume citric acid or to produce biogenic amines or acetoin, also showing high cultivability characteristics (short lag phase and increased biomass production).

\subsection{Influence of Abiotic Factors on Indigenous LAB Development and Malolactic Bioconversion 3.6.1. $\mathrm{PH}$}

$\mathrm{PH}$, along with temperature, is an essential parameter in biosynthesis processes, limiting the development of LAB species, determining which species will survive and develop as well as the growth rate of the bacteria [10]. Regarding the tested LAB strains, a $\mathrm{pH}$ above 3.5 allowed the normal development of bacterial cells. Lowering the $\mathrm{pH}$ to 3.0 hindered bacterial growth, but did not inhibit it. The lag phase was prolonged mainly in the case of the L. plantarum strain R1-1, to over five days (Figure 7a). For O. oeni strain 13-7, the lag phase at $\mathrm{pH} 3.0$ was shorter (three days) and the final value of OD $600 \mathrm{~nm}$ was higher than in the case of L. plantarum strain (Figure 7c).

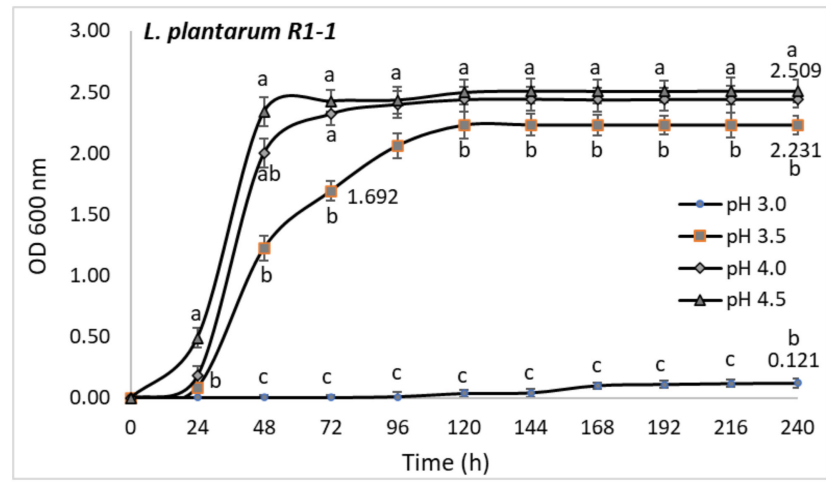

(a)

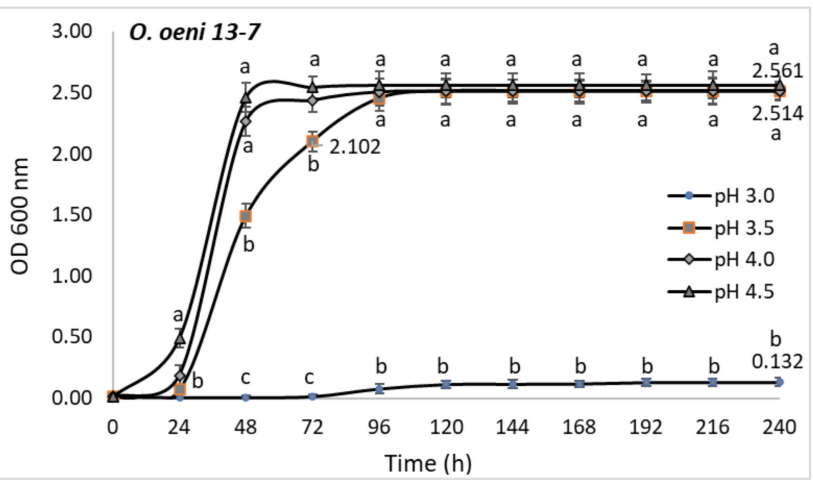

(c)

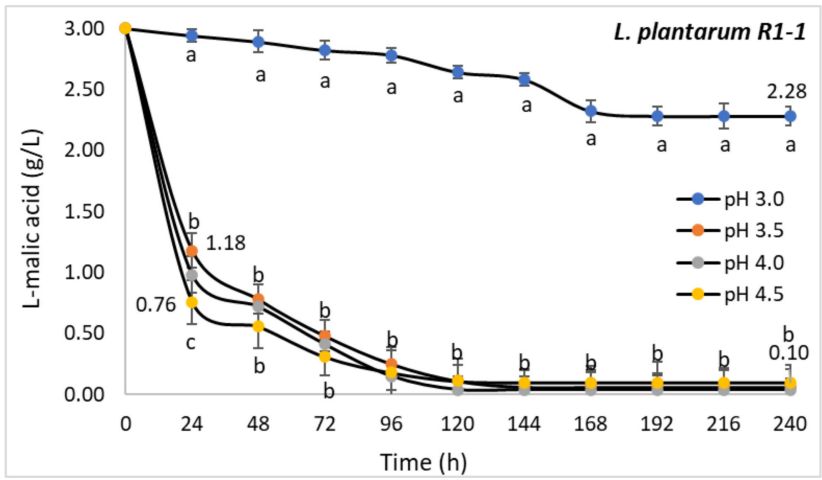

(b)

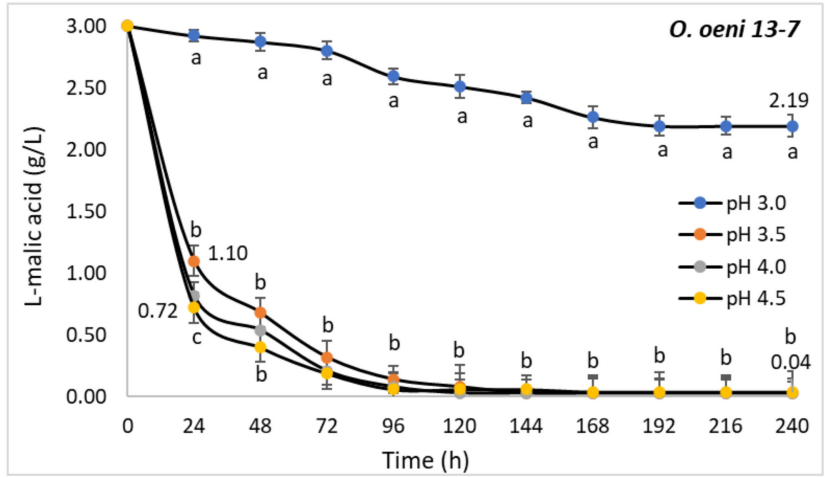

(d)

Figure 7. Influence of $\mathrm{pH}$ on cell development and malic acid metabolism of Lactobacillus plantarum strain R1-1 (a,b) and Oenococcus oeni strain 13-7 (c,d). Cells incubated in MRS-TJ broth $\left(10^{6} \mathrm{CFU} / \mathrm{mL}\right)$ at $28{ }^{\circ} \mathrm{C}$. Each value is the mean of a triplicate experiment; error bars indicate standard deviation $( \pm)$. In all cases the standard deviation was lower than $10 \%$ of the mean value. Different letters within the same column indicate significant differences between data $(p<0.05)$.

The maximum optical density of the culture (OD $600 \mathrm{~nm}$ ) was reached in the medium with $\mathrm{pH} 4.5$ after about three days of incubation for L. plantarum strain R1-1 (2.509) and after two days of incubation for O. oeni strain 13-7 (2.561). At the same time, the degradation of malic acid was not influenced at $\mathrm{pH}$ values between 3.5 and 4.5 , both strains managed to consume malic acid in high proportions $(>90 \%)$. At $\mathrm{pH} 3.0$, the amount of malic acid metabolized was significantly lower, O. oeni strain 13-7 degraded $27 \%$ of the initial malic acid (Figure $7 \mathrm{~b}$ ), while L. plantarum strain R1-1 consumed only $24 \%$ of the malic acid in ten days of incubation (Figure 7d). 


\subsubsection{Sulphur Dioxide}

The addition of sulphur dioxide $\left(\mathrm{SO}_{2}\right)$ to the fermentation medium is a traditional practice in winemaking to avoid the development of spoilage microorganisms, also as antioxidant and inhibitor of oxidizing enzymes. In the bacterial cell, the molecular form of $\mathrm{SO}_{2}$ reacts with various cellular components (e.g., proteins), affecting the growth of LAB [47]. Henick-Kling et al. [15] showed that most of $\mathrm{LAB}$ are sensitive to $\mathrm{SO}_{2}$ concentrations above $20 \mathrm{mg} / \mathrm{L}$, while at concentrations higher than $150 \mathrm{mg} / \mathrm{L} \mathrm{SO}_{2} \mathrm{MLF}$ can no longer take place. In the current study, total $\mathrm{SO}_{2}$ concentrations between 10 and $50 \mathrm{mg} / \mathrm{L}$ did not affect the normal development of the tested bacterial cultures, the exponential growth phase taking place in less than $24 \mathrm{~h}$, and the maximum optical density of the cultures being reached in $48 \mathrm{~h}$. Increasing $\mathrm{SO}_{2}$ concentration up to $70 \mathrm{mg} / \mathrm{L}$ led to a significant decrease in final cell density by about $17 \%$ in the case of L. plantarum strain R1-1 (Figure 8a) and only $15 \%$ in the case of O. oeni strain 13-7 (Figure 8c). Regardless of the dose of $\mathrm{SO}_{2}$ used, the degradation of malic acid occurred in a proportion of over $90 \%$ in the first five days of incubation (Figure 8b,d).

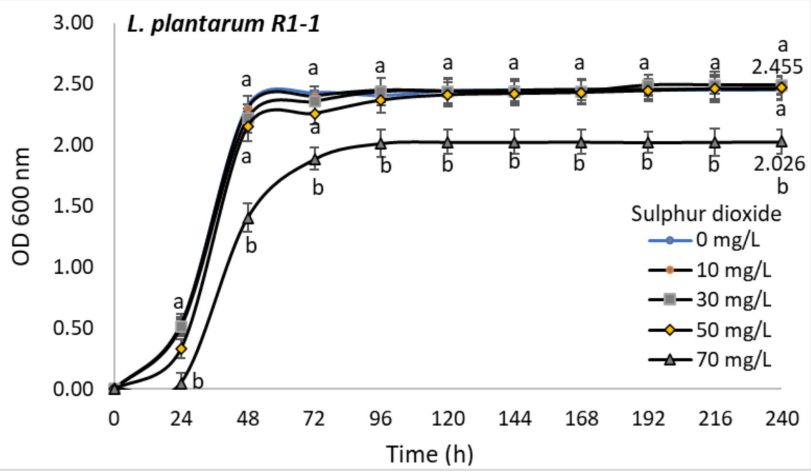

(a)

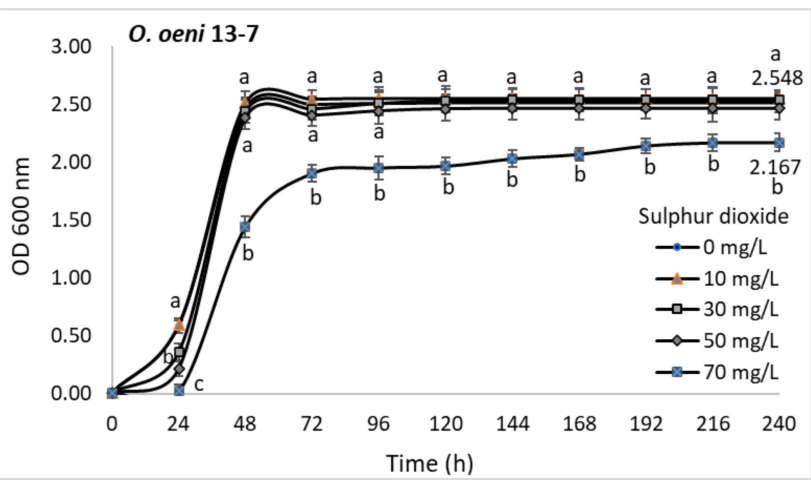

(c)

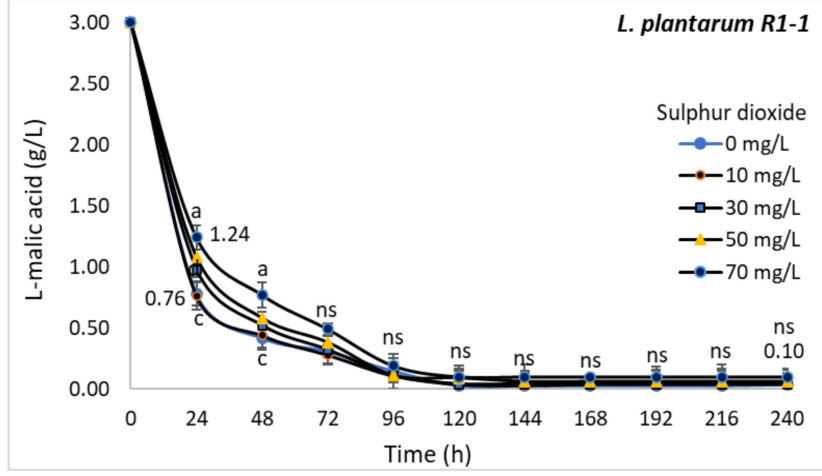

(b)

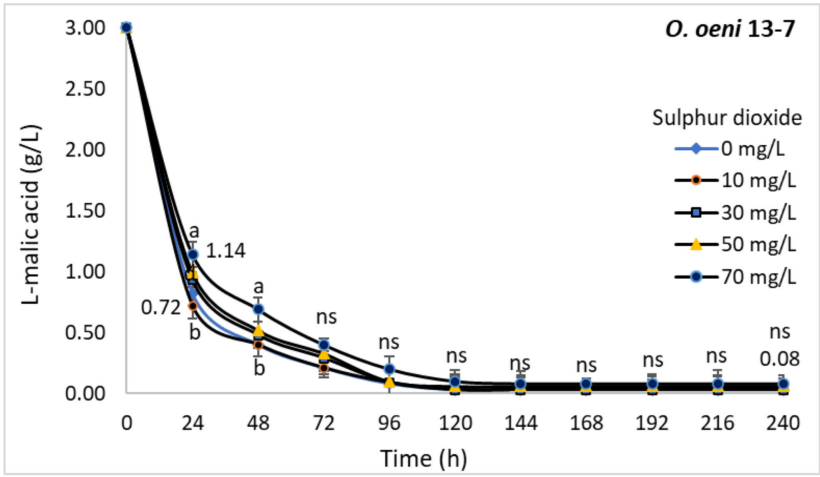

(d)

Figure 8. Influence of sulphur dioxide on cell development and malic acid metabolism of Lactobacillus plantarum strain R1-1 (a,b) and Oenococcus oeni strain 13-7 (c,d). Cells incubated in MRS-TJ broth (10 6 $\mathrm{CFU} / \mathrm{mL}$ ) at $28^{\circ} \mathrm{C}$. Each value is the mean of a triplicate experiment, error bars indicate standard deviation $( \pm)$. In all cases the standard deviation was lower than $10 \%$ of the mean value. Different letters within the same column indicate significant differences between data $(p<0.05)$.

However, in the first two days of incubation, statistically significant differences were registered between the malic acid amount degraded in the control (without $\mathrm{SO}_{2}$ ) and the samples with $\mathrm{SO}_{2}$ concentrations between 30 and $70 \mathrm{mg} / \mathrm{L}$.

\subsubsection{Temperature}

Temperature influences the rate of cell growth, the lag phase duration, and the density of the active population of lactic acid bacteria [10]. The wine LAB are mesophilic species, 
and the tolerance to low temperature appears to be a strain level characteristic. HenickKling et al. [15] have shown that the optimal growth rate of $O$. oeni strains is close to $25{ }^{\circ} \mathrm{C}$, while Ribéreau-Gayon et al. [48] reported that the optimum temperature for $O$. oeni growth in wine is $20^{\circ} \mathrm{C}$. However, the temperature during MLF should be between 18 and $25{ }^{\circ} \mathrm{C}$ to ensure optimum malolactic activity $[10,16]$.

In the case of the tested indigenous LAB isolates, the temperature significantly influenced both the cell growth and the degradation of malic acid. Mainly, the lag phase was affected by increasing its duration up to 3 days with the decrease of the temperature to $15^{\circ} \mathrm{C}$. At $22^{\circ} \mathrm{C}$, both LAB straines reached maximum cell density after five days, while at $35^{\circ} \mathrm{C}$ the lag phase unfolded very quickly and the maximum cell density was reached in $48 \mathrm{~h}$. However, the O. oeni strain withstood low temperatures better (Figure 9c), the optical density of the bacterial culture being higher in comparison to L. plantarum strain (Figure 9a).

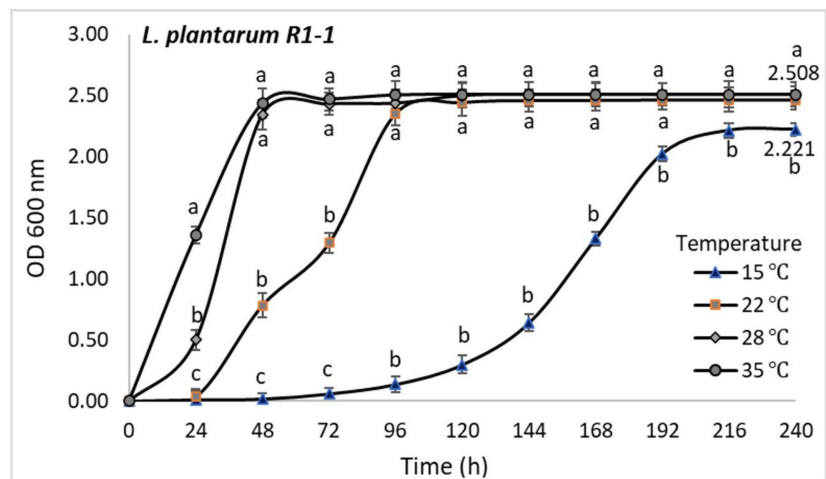

(a)

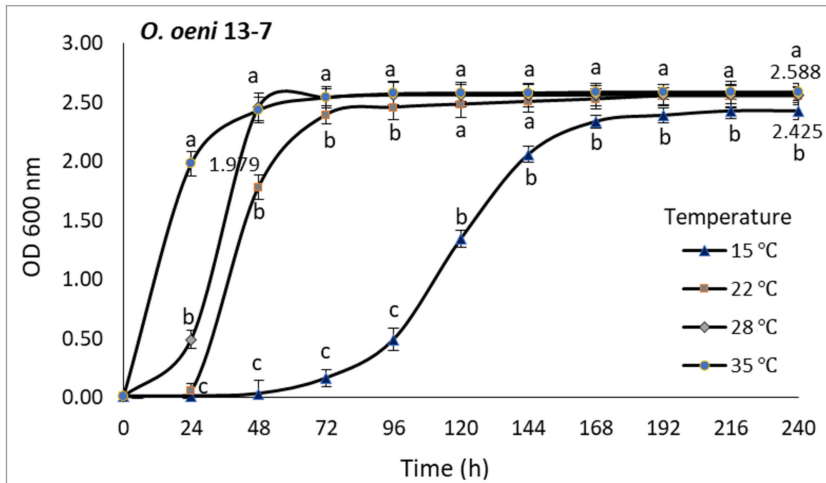

(c)

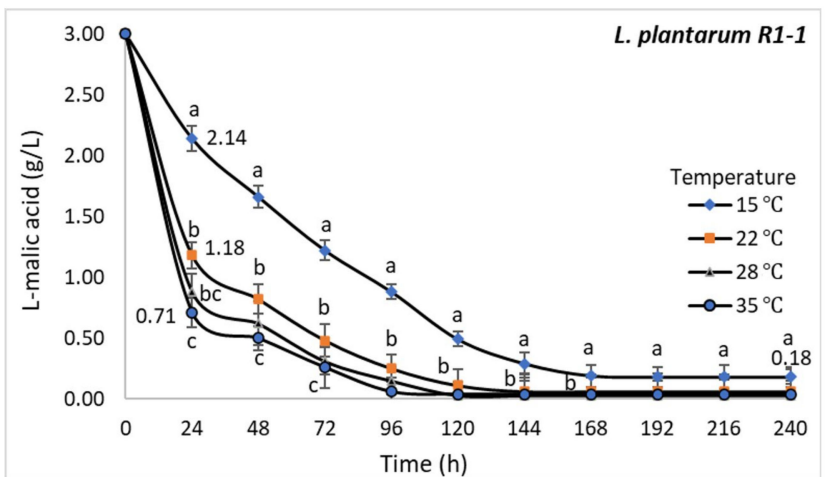

(b)

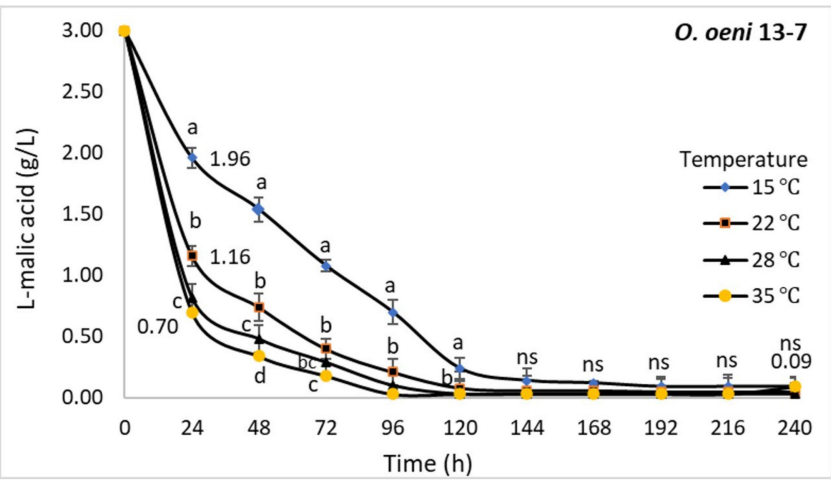

(d)

Figure 9. Influence of incubation temperature on cell development and malic acid metabolism of Lactobacillus plantarum strain R1-1 (a,b) and Oenococcus oeni strain 13-7 (c,d). Cells incubated in MRS$\mathrm{TJ}$ broth $\left(10^{6} \mathrm{CFU} / \mathrm{mL}\right)$ at different temperatures. Each value is the mean of a triplicate experiment, error bars indicate standard deviation $( \pm)$. In all cases the standard deviation was lower than $10 \%$ of the mean value. Different letters within the same column indicate significant differences between data $(p<0.05)$.

Although both tested bacterial strains were able to survive at $15^{\circ} \mathrm{C}$, the conversion of malic acid was slow and lasted longer. In $24 \mathrm{~h}$ at $15^{\circ} \mathrm{C}$, L. plantarum strain R1-1 succeeded the degradation of $28.6 \%$ of the malic acid (Figure $9 \mathrm{~b}$ ), while O. oeni strain $13-7$ metabolized $34.6 \%$ of the initial malic acid (Figure $9 \mathrm{~d}$ ). After the 10 days of incubation, over $90 \%$ of malic acid was metabolized by both LAB strains, but significant concentrations of residual malic acid were identified in the L. plantarum strain R1-1 medium. According to Krieger-Weber et al. [49], low temperatures (around $10{ }^{\circ} \mathrm{C}$ ) are not lethal for LAB strains but decrease their enzymatic activity. 


\subsubsection{Ethanol}

Ethanol strongly interferes with the growth and metabolic activity of LAB $[10,50]$. Lactobacillus strains are more tolerant to high ethanol concentrations than O. oeni [37]. In the current study, the presence of ethanol in the growth medium has significantly hindered LAB isolates cell development. If at an alcoholic strength of $10 \%(v / v)$ the lag phase lasted for two days, the increase of the ethanol concentration to $14 \%(v / v)$ led to a lag phase extended up to four days for the L. plantarum strain R1-1 and to five days for O. oeni strain 13-7. Thus, the final cell density in the medium with $14 \%(v / v)$ ethanol was about $67 \%$ lower in the case of the L. plantarum strain R1-1 (0.824) (Figure 10a) and only 50\% lower for the O. oeni strain 13-7 (1.187) (Figure 10c) compared to ethanol-free cultures. These results are consistent with those obtained by Lonvaud-Funel [40], which showed that $O$. oeni usually grows more slowly than other $\mathrm{LAB}$, but in the end predominates due to its high tolerance to the combination of ethanol and acid.

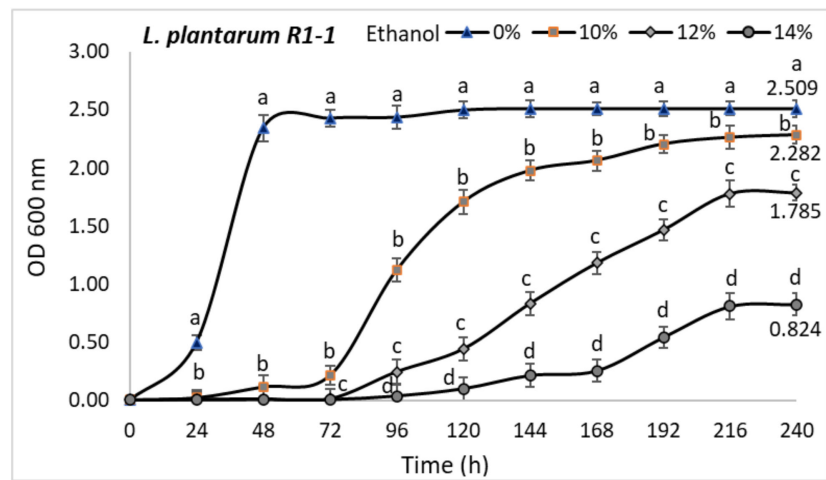

(a)

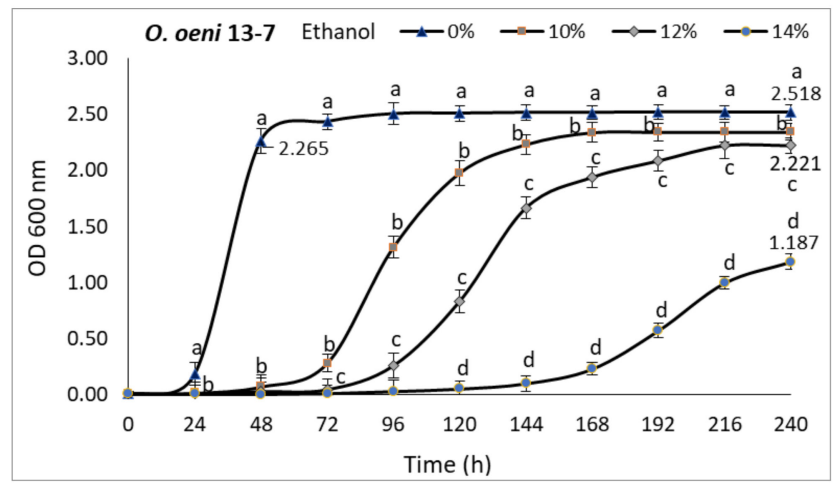

(c)

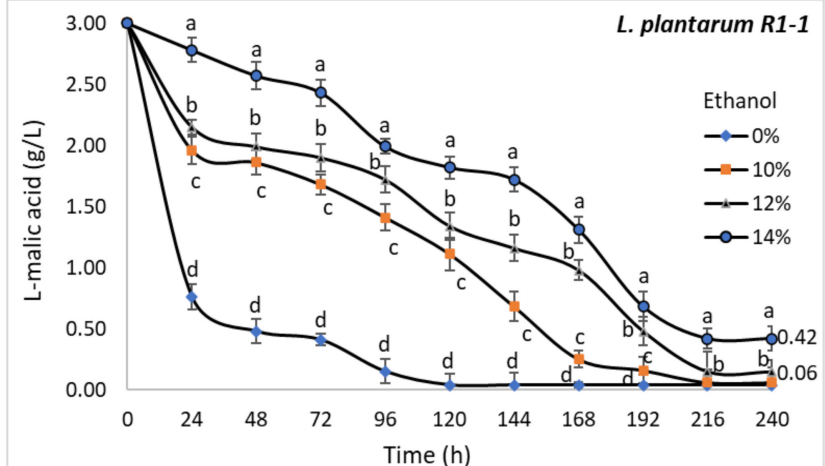

(b)

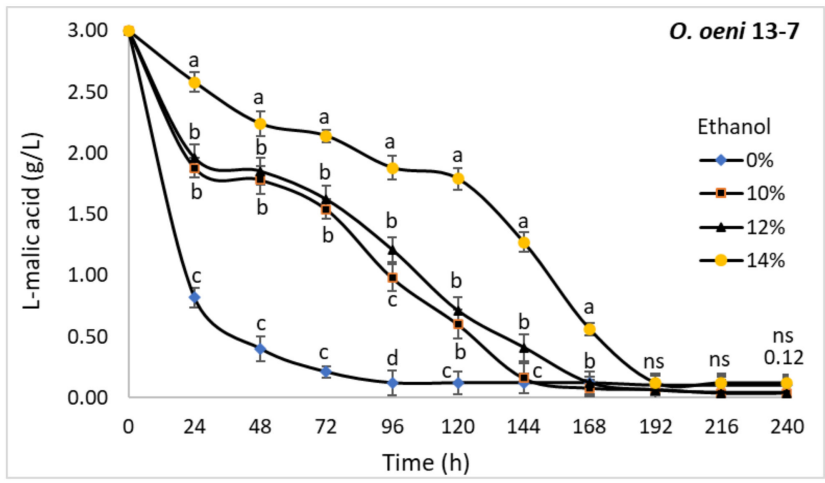

(d)

Figure 10. Influence of ethanol concentration on cell development and malic acid metabolism of Lactobacillus plantarum strain R1-1 (a,b) and Oenococcus oeni strain 13-7 (c,d). Cells incubated in MRS$\mathrm{TJ}$ broth $\left(10^{6} \mathrm{CFU} / \mathrm{mL}\right)$ at $28^{\circ} \mathrm{C}$. Each value is the mean of a triplicate experiment; error bars indicate standard deviation $( \pm)$. In all cases the standard deviation was lower than $10 \%$ of the mean value. Different letters within the same column indicate significant differences between data $(p<0.05)$.

The degradation of malic acid showed fluctuating dynamics, but both strains L. plantarum R1-1 (Figure 10b) and O. oeni 13-7 (Figure 10d) consumed more than $90 \%$ of the malic acid during the 10 days of incubation at $28{ }^{\circ} \mathrm{C}$, regardless of the ethanol concentration. In similar conditions, Bravo-Ferrada et al. reported that high ethanol concentrations negatively influenced only the development of different $O$. oeni strains, not their malolactic activity [26]. However, the ethanol tolerance of LAB is very strain dependent [49]. 


\subsubsection{Malic Acid}

Malic acid is the second major acid of grape wines, in concentrations that may vary from 2.0 to $5.0 \mathrm{~g} / \mathrm{L}$ in grapes from cool climate to $1.0-2.0 \mathrm{~g} / \mathrm{L}$ in musts from warm climates [10,51]. For this reason it is necessary for LAB strains to be able to convert different concentrations of malic acid depending on the climate area, cultivar, and type of wine. For both isolated LAB, the optical density of the bacterial cells did not significantly change with the increase of malic acid concentrations from 2 to $5 \mathrm{~g} / \mathrm{L}$. During the 10 days of incubation, the values followed the same trend up to an optical density between 2.487 and 2.509 for L. plantarum strain R1-1 (Figure 11a), and up to 2.561 for O. oeni strain 13-7 (Figure 11c).

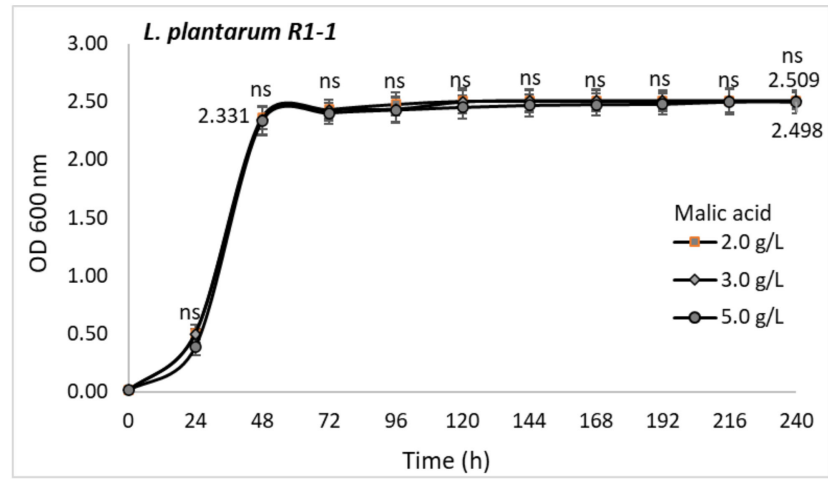

(a)

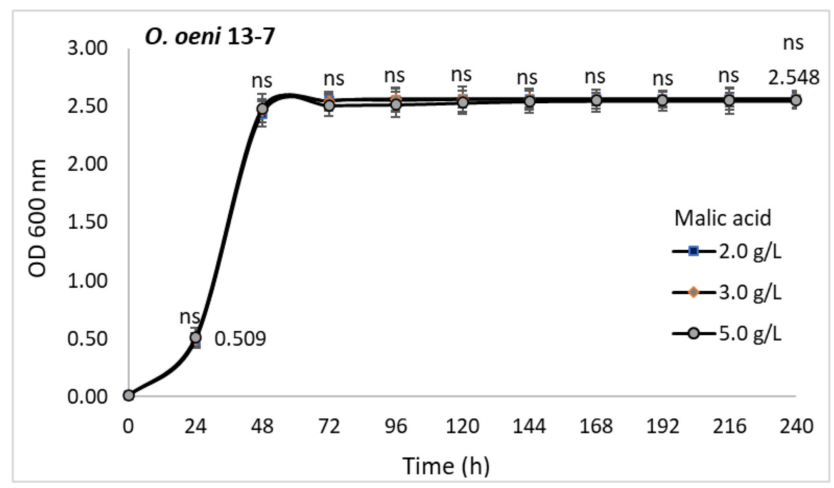

(c)

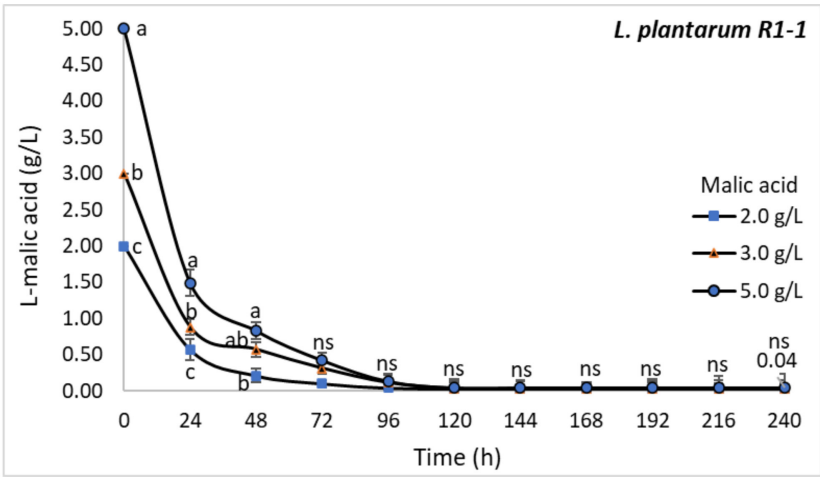

(b)

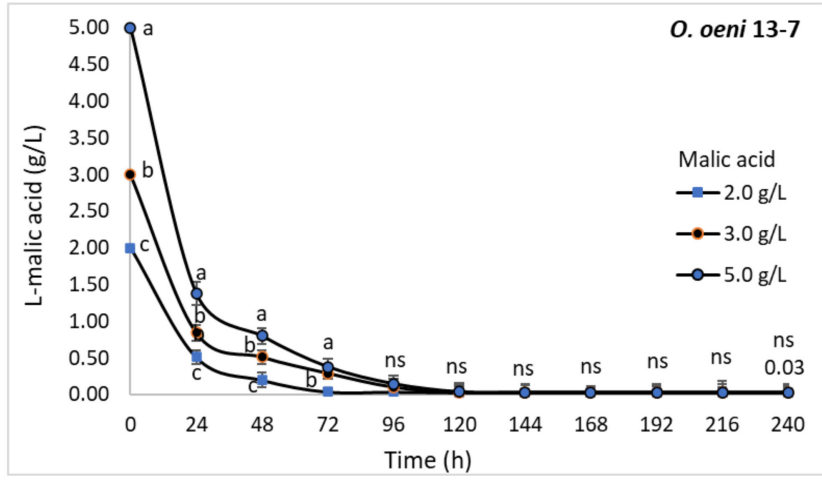

(d)

Figure 11. Influence of malic acid concentration on cell development and malolactic capacity of Lactobacillus plantarum strain R1-1 (a,b) and Oenococcus oeni strain 13-7 (c,d). Cells incubated in MRSTJ broth $\left(10^{6} \mathrm{CFU} / \mathrm{mL}\right)$ at $28^{\circ} \mathrm{C}$. Each value is the mean of a triplicate experiment; error bars indicate standard deviation $( \pm)$. In all cases the standard deviation was lower than $10 \%$ of the mean value. Different letters within the same column indicate significant differences between data $(p<0.05)$.

Regardless of the initial acid concentrations, tested LAB consumed up to $99 \%$ of malic acid during 10 days of incubation in MRS-TJ broth at $28^{\circ} \mathrm{C}(\mathrm{pH} 4.0)$ (Figure 11b,d). In this case, a clear overall correlation between optical density at $600 \mathrm{~nm}$ and malic acid conversion was found $\left(\mathrm{r}^{2}=-0.8234\right)$.

\section{Conclusions}

Given the importance of the biological agents involved in the wine malolactic bioconversion, 67 indigenous catalase-negative and Gram-positive lactic acid bacteria strains were isolated from red wines undergoing spontaneous malolactic fermentation. After specific screening procedures and identification (API $50 \mathrm{CH}$ ), two bacterial strains belonging to the species Oenococcus oeni (strain 13-7) and Lactobacillus plantarum (strain R1-1) showing high yield of malic acid metabolization, unable to produce biogenic amines and to consume citrate, and with active extracellular enzymes related to wine aroma, were retained and 
further characterized. Tested in synthetic medium, new indigenous LAB strains were grown and metabolized over $98 \%$ of the malic acid at high ethanol concentrations (10-14\% $v / v)$, low $\mathrm{pH}(>3.0)$, total $\mathrm{SO}_{2}$ doses up to $70 \mathrm{mg} / \mathrm{L}$ and temperatures between 15 and $35{ }^{\circ} \mathrm{C}$, showing high potential for future use in the winemaking process as malolactic bacterial starter cultures, in order to obtain high quality wines with balanced acidity and increased typicity.

Author Contributions: Conceptualization, R.V.F. and S.I.D.; methodology, R.V.F.; software, F.D.B.; validation, S.I.D. and C.-I.B.; formal analysis, R.V.F.; investigation, R.M.F.; resources, C.-I.B. and A.N.; writing-original draft preparation, R.V.F.; visualization, S.I.D. and A.M. All authors have read and agreed to the published version of the manuscript.

Funding: This research was funded by the Academy of Agricultural and Forestry Sciences "Gheorghe Ionescu-Sisesti" Romania, grant number 2180/19.09.2018 and by a grant of the Romanian Ministry of Education and Research, CNCS-UEFISCDI, project number PN-III-P2-2.1-PED-20195360. The APC was funded by the University of Agricultural Sciences and Veterinary Medicine Cluj-Napoca, Romania.

Institutional Review Board Statement: Not applicable.

Informed Consent Statement: Not applicable.

Data Availability Statement: All data is contained within the article.

Acknowledgments: The authors gratefully acknowledge the University of Agricultural Sciences and Veterinary Medicine Cluj-Napoca for financial support.

Conflicts of Interest: The authors declare no conflict of interest.

\section{References}

1. Grainger, K.; Tattersall, H. Red winemaking. In Wine Production and Quality, 2nd ed.; Grainger, K., Tattersall, H., Eds.; WileyBlackwell: Hoboken, NJ, USA, 2016; pp. 82-91. [CrossRef]

2. Virdis, C.; Krista, S.; Bartowsky, E.; Jiranek, V. Lactic acid bacteria in wine: Technological advances and evaluation of their functional role. Front. Microbiol. 2021, 11, 612118. [CrossRef]

3. Capozzi, V.; Tufariello, M.; De Simone, N.; Fragasso, M.; Grieco, F. Biodiversity of oenological lactic acid bacteria: Species-and strain-dependent plus/minus effects on wine quality and safety. Fermentation 2021, 7, 24. [CrossRef]

4. Lerm, E.; Engelbrecht, L.; Du Toit, M. Malolactic fermentation: The ABC's of MLF. S. Afr. J. Enol. Vitic. 2010, 31, 186-212. [CrossRef]

5. Costantini, A.; Garcia-Moruno, E.; Moreno-Arribas, M.V. Biochemical transformations produced by malolactic fermentation. In Wine Chemistry and Biochemistry; Moreno-Arribas, M.V., Polo, M.C., Eds.; Springer Science: New York, NY, USA, 2009; pp. 28-58.

6. Liu, K.; Gao, D.; Liu, Z.; Li, N.; Bian, Y.; Zheng, R.; Zhang, X. Screening of lactic acid bacteria with high activities malolactic enzyme and analysis of indigenous flora in red wine. J. Chem. Pharm. Res. 2014, 6, 136-144.

7. Singh, R.; Gupta, N.; Goswami, V.K.; Gupta, R. A simple activity staining protocol for lipases and esterases. Appl. Microbiol. Biotechnol. 2006, 70, 679-682. [CrossRef] [PubMed]

8. Bravo-Ferrada, B.M.; Hollmann, A.; Delfederico, L.; Valdés La Hens, D.; Caballero, A.; Semorile, L. Patagonian red wines: Selection of Lactobacillus plantarum isolates as potential starter cultures for malolactic fermentation. World J. Microbiol. Biotechnol. 2013, 29, 1537-1549. [CrossRef]

9. Maicas, S.; Gonzalez-Cabo, P.; Ferrer, S.; Pardo, I. Production of Oenococcus oeni biomass to induce malolactic fermentation in wine by control of pH and substrate addition. Biotechnol. Lett. 1999, 21, 349-353. [CrossRef]

10. Bauer, R.; Dicks, L.M.T. Control of malolactic fermentation in wine: A review. S. Afr. J. Enol. Vitic. 2004, 25, 74-88. [CrossRef]

11. Toe, C.J.; Foo, H.L.; Loh, T.C.; Mohamad, R.; Abdul Rahim, R.; Idrus, Z. Extracellular proteolytic activity and amino acid production by lactic acid bacteria isolated from Malaysian foods. Int. J. Mol. Sci. 2019, 20, 1777. [CrossRef]

12. De Vos, P.; Garrity, G.M.; Jones, D.; Krieg, N.R.; Ludwig, W.; Rainey, F.A.; Schleifer, K.-H.; Whitman, W.B. Bergey's Manual of Systematic Bacteriology. Volume 3. The Firmicutes; Springer: New York, NY, USA, 2009.

13. Krieger-Weber, S.; Silvano, A.; Loubser, P. Environmental factors affecting malolactic fermentation. In Malolactic FermentationImportance of Wine Lactic Acid Bacteria in Winemaking; Morenzoni, R., Ed.; Lallemand Inc.: Montréal, QC, Canada, 2015 ; pp. 131-146.

14. McKay, M.; Buglass, A.J.; Lee, C.G. Malolactic fermentation. In Handbook of Alcoholic Beverages; Buglass, A.J., Ed.; Wiley: Chichester, UK, 2011; pp. 96-113. [CrossRef]

15. Henick-Kling, T.; Acree, T.E.; Krieger, S.A.; Laurent, M.H. Sensory aspects of malolactic fermentation. In Proceedings of the 8th Australian Wine Industry Technical Conference, Melbourne, Australia, 25-29 October 1992; Winetitles: Adelaide, Australia, 1993; pp. 148-152. 
16. Krieger, S. The history of malolactic bacteria in wine. In Malolactic Fermentation in Wine-Understanding the Science and the Practice; Morenzoni, R., Ed.; Lallemand Inc.: Montréal, QC, Canada, 2005; pp. 3.1-3.9.

17. Andorrà, I.; Miró, G.; Espligares, N.; Maria Mislata, A.; Puxeu, M.; Ferrer-Gallego, R. Wild yeast and lactic acid bacteria of wine In Yeasts in Biotechnology; Basso, T.P., Ed.; IntechOpen: London, UK, 2019. [CrossRef]

18. OIV (International Organisation of Vine and Wine). Compendium of International Methods of Wine and Must Analysis; OIV: Paris, France, 2016; Volume 1.

19. De Man, J.C.; Rogosa, M.; Sharpe, M.E. A medium for the cultivation of Lactobacilli. J. Appl. Microbiol. 1960, 23, 130-135. [CrossRef]

20. Saguir, F.M.; Campos, I.E.L.; Maturano, C.; Manca de Nadra, M.C. Identification of dominant lactic acid bacteria isolated from grape juices. Assessment of its biochemical activities relevant to flavor development in wine. Int. J. Wine Res. 2009, 1, 175-185. [CrossRef]

21. Bravo-Ferrada, B.M.; Tymczyszyn, E.E.; Gómez-Zavaglia, A.; Semorile, L. Effect of acclimation medium on cell viability, membrane integrity and ability to consume malic acid in synthetic wine by oenological Lactobacillus plantarum strains. J. Appl. Microbiol. 2014, 116, 360-367. [CrossRef]

22. Rosi, I.; Vinella, M.; Domizio, P. Characterization of $\beta$-glucosidase activity in yeasts of oenological origin. J. Appl. Microbiol. 1994, 77, 519-527. [CrossRef]

23. Carissimi, M.; Stopiglia, C.D.O.; Furtado de Souza, T.; Corbellini, V.A.; Scroferneker, M.L. Comparison of lipolytic activity of Sporothrix schenckii strains utilizing olive oil-Rhodamine B and Tween 80. Tecno-Lógica 2007, 11, 33-36.

24. Ouattara, D.H.; Ouattara, H.G.; Adom, J.N.; Goualié, B.G.; Koua, G.A.; Doué, G.G.; Niamke, S.L. Screening of lactic acid bacteria capable to breakdown citric acid during Ivorian cocoa fermentation and response of bacterial strains to fermentative conditions. Br. Biotechnol. J. 2016, 10, 1-10. [CrossRef]

25. Maijala, R.L. Formation of histamine and tyramine by some lactic acid bacteria in MRS-broth and modified decarboxylation agar. Lett. Appl. Microbiol. 1993, 17, 40-43. [CrossRef]

26. Bravo-Ferrada, B.M.; Delfederico, L.; Hollmann, A.; Valdés La Hens, D.; Curilén, Y.; Caballero, A.; Semorile, L. Oenococcus oeni from Patagonian red wines: Isolation, characterization and technological properties. Int. J. Microbiol. Res. 2011, 3, 48-55. [CrossRef]

27. Muñoz, R.; Moreno-Arribas, M.V.; De las Rivas, B. Lactic acid bacteria. In Molecular Wine Microbiology; Carrascosa, A.V., Muñoz, R., González, R., Eds.; Academic Press: Cambridge, MA, USA, 2011; pp. 191-226. [CrossRef]

28. Dicks, L.M.T.; Endo, A. Taxonomic status of lactic acid bacteria in wine and key characteristics to differentiate species. S. Afr. J. Enol. Vitic. 2009, 30, 72-90. [CrossRef]

29. De Orduna, R.M. Climate change associated effects on grape and wine quality and production. Food Res. Int. 2010, 43, 1844-1855. [CrossRef]

30. Bokulich, N.A.; Thorngate, J.H.; Richardson, P.M.; Mills, D.A. Microbial biogeography of wine grapes is conditioned by cultivar, vintage, and climate. Proc. Natl. Acad. Sci. USA 2014, 111, E139-E148. [CrossRef]

31. Khalid, K. An overview of lactic acid bacteria. Int. J. Biosci. 2011, 1, 1-13.

32. Costello, P. The chemistry of malolactic fermentation. In Malolactic Fermentation-Importance of Wine Lactic Acid Bacteria in Winemaking; Morenzoni, R., Ed.; Lallemand Inc.: Montréal, QC, Canada, 2015; pp. 33-48.

33. Drozdz, I.; Makarewicz, M.; Tuszynski, T. Isolation and identification of microorganisms including lactic acid bacteria and teir use in microbial deacidification of wines from domestic vineyards. Pol. J. Microbiol. 2013, 62, 331-334. [CrossRef]

34. Izquierdo, P.M.; Garcia, E.; Martinez, J.; Chacon, J.L. Selection of lactic bacteria to induce malolactic fermentation in red wine of cv. Cencibel. Vitis 2004, 43, 149-153. [CrossRef]

35. Spano, G.; Beneduce, L.; Tarantino, D.; Zapparoli, G.; Massa, S. Characterization of Lactobacillus plantarum from winemust by PCR species-specific and RAPD-PCR. Lett. Appl. Microbiol. 2002, 35, 370-374. [CrossRef]

36. Bartowsky, E.J.; Henschke, P.A. Malolactic fermentation and wine flavour. Aust. Grapegrow. Winemak. 1995, 378, 83-94.

37. Davis, C.R.; Wibowo, D.; Fleet, G.H.; Lee, T.H. Properties of wine lactic acid bacteria: Their potential enological significance. Am. J. Enol. Vitic. 1988, 39, 137-142.

38. Lerm, E. The Selection and Characterisation of Lactic Acid Bacteria to Be Used as a Mixed Starter Culture for Malolactic Fermentation. Master's Thesis, Stellenbosch University, Department of Viticulture and Oenology, Faculty of AgriSciences, Stellenbosch, South Africa, 2010. Available online: https:/ / core.ac.uk/download/pdf/37324200.pdf (accessed on 12 May 2019).

39. Swiegers, J.H.; Bartowsky, E.J.; Henschke, P.A.; Pretorius, I.S. Yeast and bacterial modulation of wine aroma and flavour. Aust. J. Grape Wine Res. 2005, 11, 139-173. [CrossRef]

40. Lonvaud-Funel, A. Lactic acid bacteria in the quality improvement and depreciation of wine. Antonie Leeuwenhoek 1999, 76, 317-331. [CrossRef]

41. Bartowsky, E.J.; Henschke, P.A. The "buttery" attribute of wine-diacetyl-desirability, spoilage and beyond. Int. J. Food Microbiol. 2004, 96, 235-252. [CrossRef]

42. Pretorius, N.; Engelbrecht, L.; Du Toit, M. Influence of sugars and pH on the citrate metabolism of different lactic acid bacteria strains in a synthetic wine matrix. J. Appl. Microbiol. 2019, 127, 1490-1500. [CrossRef]

43. Galgano, F.; Caruso, M.; Favati, F. Biogenic amines in wines: A review. In Red Wine and Health; O'Byrne, P., Ed.; Nova Science Publishers: New York, NY, USA, 2009; pp. 173-203. 
44. Liu, S.-Q.; Pritchard, G.G.; Hardman, M.J.; Pilone, G.J. Arginine catabolism in wine lactic acid bacteria: Is it via the arginine deaminase pathway or the arginase-urease pathway? J. Appl. Bacteriol. 1996, 81, 486-492.

45. Soufleros, E.; Barrios, M.L.; Bertrand, A.S. Correlation between the content of biogenic amines and other wine compounds. Am. J. Enol. Vitic. 1998, 49, 266-278.

46. Fugelsang, K.; Edwards, C. Wine Microbiology; Springer: New York, NY, USA, 2010.

47. Carreté, R.; Vidal, M.T.; Bordons, A. Inhibitory effect of sulphur dioxide and other stress compounds in wine on the ATPase activity of Oenococcus oeni. FEMS Microbiol. Lett. 2002, 211, 155-159. [CrossRef]

48. Ribereau-Gayon, P.; Dubourdieu, D.; Doneche, B.; Lonvaud, A. Handbook of Enology. Volume 1. The Microbiology of Wine and Vinifications; Wiley: Chichester, UK, 2006.

49. Krieger-Weber, S.; Heras, J.M.; Suarez, C. Lactobacillus plantarum, a new biological tool to control malolactic fermentation: A review and an outlook. Beverages 2020, 6, 23. [CrossRef]

50. Zhao, H.; Liu, L.; Yuan, L.; Hu, K.; Peng, S.; Li, H.; Wang, H. Mechanism analysis of combined acid-and-ethanol shock on Oenococcus oeni using RNA-Seq. Eur. Food Res. Technol. 2020, 246, 1637-1646. [CrossRef]

51. Cotea, V.D.; Zănoagă, C.; Cotea, V.V. Tratat de Oenochimie [Treatise on Oenochemistry]; Editura Academiei Române: Bucharest, Romania, 2009; Volume I. 